\title{
The first countrywide monitoring of selected POPs: Polychlorinated biphenyls (PCBs), polybrominated diphenyl ethers (PBDEs) and selected organochlorine pesticides (OCPs) in the atmosphere of Turkey
}

\author{
Perihan Binnur Kurt-Karakus ${ }^{\mathrm{a}, *}$, Tugba Ugranli-Cicek ${ }^{\mathrm{b}}$, Sait C. Sofuoglu ${ }^{\mathrm{b}}$, Halil Celik ${ }^{\mathrm{c}}$, \\ Elif Gungormus ${ }^{\mathrm{b}}$, Kadir Gedik ${ }^{\mathrm{c}}$, Aysun Sofuoglu ${ }^{\mathrm{d}}$, Hatice Eser Okten ${ }^{\mathrm{b}}$, Askın Birgul ${ }^{\mathrm{a}}$, \\ Henry Alegria $^{\mathrm{e}}$, Kevin C. Jones ${ }^{\mathrm{f}}$
}

\footnotetext{
${ }^{a}$ Bursa Technical University, Faculty of Engineering, Department of Environmental Engineering, Mimar Sinan Mahallesi, Mimar Sinan Bulvari Eflak Caddesi No:177 16310 Yildirim, Bursa, Turkey

${ }^{\mathbf{b}}$ Izmir Institute of Technology, Department of Environmental Engineering, Gulbahce, Urla, 35430, İzmir, Turkey

${ }^{c}$ Akdeniz University, Faculty of Engineering, Department of Environmental Engineering, Dumlupinar Bulvari, 07058, Antalya, Turkey

d Izmir Institute of Technology, Department of Chemical Engineering, Gulbahce, Urla, 35430, Izmir, Turkey

e University of South Florida St Petersburg, Department of Environmental Science, Policy \& Geography, 140 7th Avenue South, St Petersburg, FL, 33701, USA

${ }^{\mathrm{f}}$ Lancaster Environment Center, Lancaster University, Lancaster, LA1 4YQ United Kingdom
}

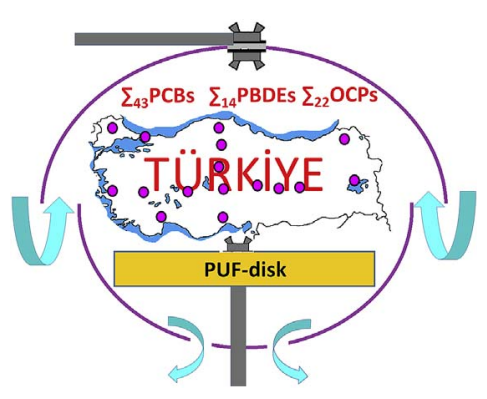

\section{A R T I C L E I N F O}

\section{Keywords:}

PCBs

OCPs

PBDEs

Passive sampling

Urban and rural

Turkey

\begin{abstract}
A B S T R A C T
Atmospheric levels of 43 PCBs, 22 OCPs, and 14 PBDEs were determined in 16 cities at urban and rural sites by passive sampling to generate the first large-scale nationwide dataset of POP residues in Turkey's atmosphere. Sampling campaign was performed from May 2014 to April 2015 with three-month sampling periods at locations on east-west and north-south transects through the country to investigate seasonal and spatial variations, including long range atmospheric transport (LRAT). Factor analysis was conducted to infer on the potential sources. Overall average $\Sigma_{43}$ PCBs concentration was $108 \pm 132 \mathrm{pg} / \mathrm{m}^{3}$. PCB-118 $\left(26.3 \pm 44.6 \mathrm{pg} / \mathrm{m}^{3}\right)$ was the top congener, and penta-CBs had the highest contribution with $54.3 \%$. $\Sigma$ DDTs had the highest annual mean concentration with $134 \pm 296 \mathrm{pg} / \mathrm{m}^{3}$ among the OCP groups among which the highest concentration compound was $p$ p-DDE $\left(97.6 \pm 236 \mathrm{pg} / \mathrm{m}^{3}\right)$. Overall average concentration of $\Sigma_{14}$ PBDEs was $191 \pm 329 \mathrm{pg} / \mathrm{m}^{3}$ with the highest contribution from BDE-190 (42\%). Comparison of OCPs and PCBs concentrations detected at temperatures which were above and below annual average temperature indicated higher concentrations in the warmer periods, hence significance of secondary emissions for several OCPs and $\Sigma_{43} \mathrm{PCBs}$, as well as inference as LRAT from secondary emissions. The first nationwide POPs database constructed in this study, point to current
\end{abstract}

\footnotetext{
* Corresponding author.

E-mail address: perihan.kurt@btu.edu.tr (P.B. Kurt-Karakus).
} 
use, local secondary emissions, and LRAT for different individual compounds, and indicate the need for regular monitoring.The first country-wide passive sampling of selected POPs showed no unequivocal trends reflecting transitional location of Turkey.

\section{Introduction}

It was decided by the Grand National Assembly in April 2009 that Turkey was to become a party to the Stockholm Convention (Official Gazette, 2009a). The decision was accepted by the Council of Ministers in July 2009 (Official Gazette, 2009b) whereas the legal procedure was completed in January 2010. As is the case for many Stockholm Convention ratifying countries, certain persistent organic pollutants (POPs) such as polychlorinated biphenyls (PCBs) and polybrominated diphenyl ethers (PBDEs) were never produced in Turkey. However, many products such as transformers, capacitors and flame retarded consumer products containing these chemicals were/are in use in the country. As a country with intensive agricultural practices, organochlorine pesticides (OCPs) were also widely used in Turkey until they were banned. Moreover, Turkey receives air masses from Europe, former Soviet countries, the Arabian Peninsula, and North Africa, which makes it an interesting country in terms of POPs due to its transitional location. PCBs, PBDEs, and OCPs are considered as POPs that are best known for their persistence to degradation in the environment. Therefore, they can undergo long range atmospheric transport (LRAT), and are subject to bioaccumulation in fatty tissues and in the food chain (Li et al., 2006). Most of the subject POPs (such as heptachlor, lindane, dieldrin, chlordane, etc.) were banned around the 1980s in Turkey.

One of the main obligatory tasks required under Stockholm Convention for ratifying countries is to monitor environmental levels of banned/phased out chemicals. In this manner, many of ratifying countries have conducted long-term systematic monitoring programs. Although the country is under the obligations of the Convention since 2010, Turkey is unfortunately lacking such long-term spatial and temporal monitoring activities of POPs. There exist studies to determine occurrence and seasonality of PCBs (Gedik and Imamoglu, 2010; Yenisoy Karakas et al., 2012; Kuzu et al., 2014, 2016; Kuzu, 2016; Kuzu and Saral, 2017; Dumanoglu et al., 2017), PBDEs (Cetin and Odabasi, 2007, 2008; Odabasi et al., 2016) and OCPs (Yenisoy-Karakas et al., 2012; Kuzu, 2016) in the country. However, these studies are limited to several specific industrial and urban locations to measure seasonality of chemicals of interest.

Compared to the western part of the world, number of studies on investigation of occurrence and fate of POPs including PCBs, OCP, and PBDEs in environmental compartments in Turkey is still limited, it is certainly of an increasing interest. Sources of PCB contamination was reported to be petrochemical plants, iron steel-plants, and ship demolishing sites in the studies conducted in Aliaga (Kaya et al., 2012; Odabasi et al., 2015) and waste landfill in Hamitler (Esen, 2013). Odabasi et al. (2016) reported average concentration of $\Sigma_{41}$ PCBs in background and industrial sites in Iskenderun (Turkey) as $180 \pm 140 \mathrm{pg} / \mathrm{m}^{3}$ and $1600 \pm 900 \mathrm{pg} / \mathrm{m}^{3}$, respectively. Summer concentrations of $\Sigma_{41}$ PCBs in Kutahya province were reported in the range of $31.6 \mathrm{pg} / \mathrm{m}^{3}$ to $230.2 \mathrm{pg} / \mathrm{m}^{3}$ (average value of $125.3 \pm 33.5 \mathrm{pg} / \mathrm{m}^{3}$ ) while concentration range was $19.6 \mathrm{pg} / \mathrm{m}^{3}$ to $675,1 \mathrm{pg} / \mathrm{m}^{3}$ with an average value of $187.9 \pm 132.9 \mathrm{pg} / \mathrm{m}^{3}$ in winter (Dumanoglu et al., 2017). Average ambient gas-phase $\Sigma_{7}$ PBDE concentrations were between $189 \pm 61$ (summer) and $76 \pm 65 \mathrm{pg} / \mathrm{m}^{3}$ (winter) in Izmir (Cetin and Odabasi, 2007). Kurt-Karakus et al. (2017) reported $\Sigma_{12}$ PBDEs concentrations range between 110 and $620 \mathrm{pg} / \mathrm{m}^{3}$ in Istanbul. Gas phase $\Sigma_{23} \mathrm{OCPs}$ average concentration were in the range of $1.10 \mathrm{pg} / \mathrm{m}^{3}$ and $42.5 \mathrm{pg} / \mathrm{m}^{3}$ in Izmir (Ugranli et al., 2016). AlphaHCH showed the lowest concentration $\left(2.10 \mathrm{pg} / \mathrm{m}^{3}\right)$ while endosulfan II showed the highest concentration $\left(73.01 \mathrm{pg} / \mathrm{m}^{3}\right)$ in samples collected from Bursa province in 2008-2009 (Cindoruk and Tasdemir, 2014). The congener pattern of PCBs was similar in air of Aegean but PBDE levels were different between Greece and Turkey (Lammel et al., 2015). Additionally, uniform concentration levels of long-lived chemicals were reported to be dominated by LRAT or distribution within a region.

High volume active air sampling of POPs is a widely favored technique around the world. However, after the awareness of the fact that remote areas might also been polluted by POPs due to LRAT (Bowes and Jonkel, 1975), an alternative technique was required that provides easy access, less operation cost and labor, and, above all, has no electricity requirement. Development of passive air samplers (PAS) met these requirements, and they have been widely used for measurement of relatively long term average gas phase concentrations of POPs. Besides studies to determine ambient air POPs levels using active air samplers in Turkey (Birgul and Tasdemir, 2012; Cindoruk and Tasdemir, 2014; Kuzu et al., 2014; Odabasi and Cetin, 2012; Yolsal et al., 2014; Ugranli et al., 2016) there are limited studies conducted in Turkey using polyurethane foam passive samplers (PUF-PAS) (Kaya et al., 2012; Aydin et al., 2014; Odabasi et al., 2015, 2016; Kurt-Karakus et al., 2017; Cetin et al., 2017a,b). However, these studies were conducted in particular regions of the country and there are no studies to investigate the levels of PCBs, PBDEs and OCPs concurrently on a countrywide scale.

The aims of this study were (a) to measure atmospheric air concentrations of PCBs, OCPs, and PBDEs at a total of 32 urban and rural places located in 16 provinces at an east-west and a north-south transect in Turkey using PUF-PAS samplers, (b) to investigate spatial and seasonal variations of target chemicals, and (c) to generate the first large-scale nationwide dataset of atmospheric PCB, PBDE, and OCP levels in Turkey.

\section{Materials and methods}

\subsection{Study area and sampling program}

Sixteen provinces with urban and rural sites in Turkey were selected on the centerline from East to West and North to South in addition to the three corner locations of Turkey (Figs. 1, 3 and 4; Supplementary Material Table S1). It was recommended that the rural sites should represent a diameter of a circular area of at least $100 \mathrm{~km}$ so the distance between the sampling locations was about 250-300 km (UNEP, 2007). Ease of transport, existence of contact people to take care of the samplers, and travel safety were the other criteria considered for sampling point selections. Urban sampling locations were representative of typical urbanized areas. Background sites were chosen to be remote from any potential sources such as populated/industrialized/agrochemical application areas, to ensure that they were representative of background levels.

Three-month sampling was performed in four periods; May-July 2014 (1st period), August-October 2014 (2nd period), November 2014-January 2015 (3rd period), and February-April 2015 (4th period). The sampling durations varied from 80 to 118 days depending on the availability and travel conditions on the field (Supplementary Material Table S1). Mean temperature ranges during the sampling periods were $12.9-25.6{ }^{\circ} \mathrm{C}$ (1st period), $10.6-24.2^{\circ} \mathrm{C}$ (2nd period), $-3.6-12.8^{\circ} \mathrm{C}$ (3rd period), and $3.5-15.6^{\circ} \mathrm{C}$ (4th period).

\subsection{Chemicals and reagents}

All chromatography-grade solvents (acetone, hexane, dichloromethane, iso-octane), anhydrous sodium sulfate (granulated for 


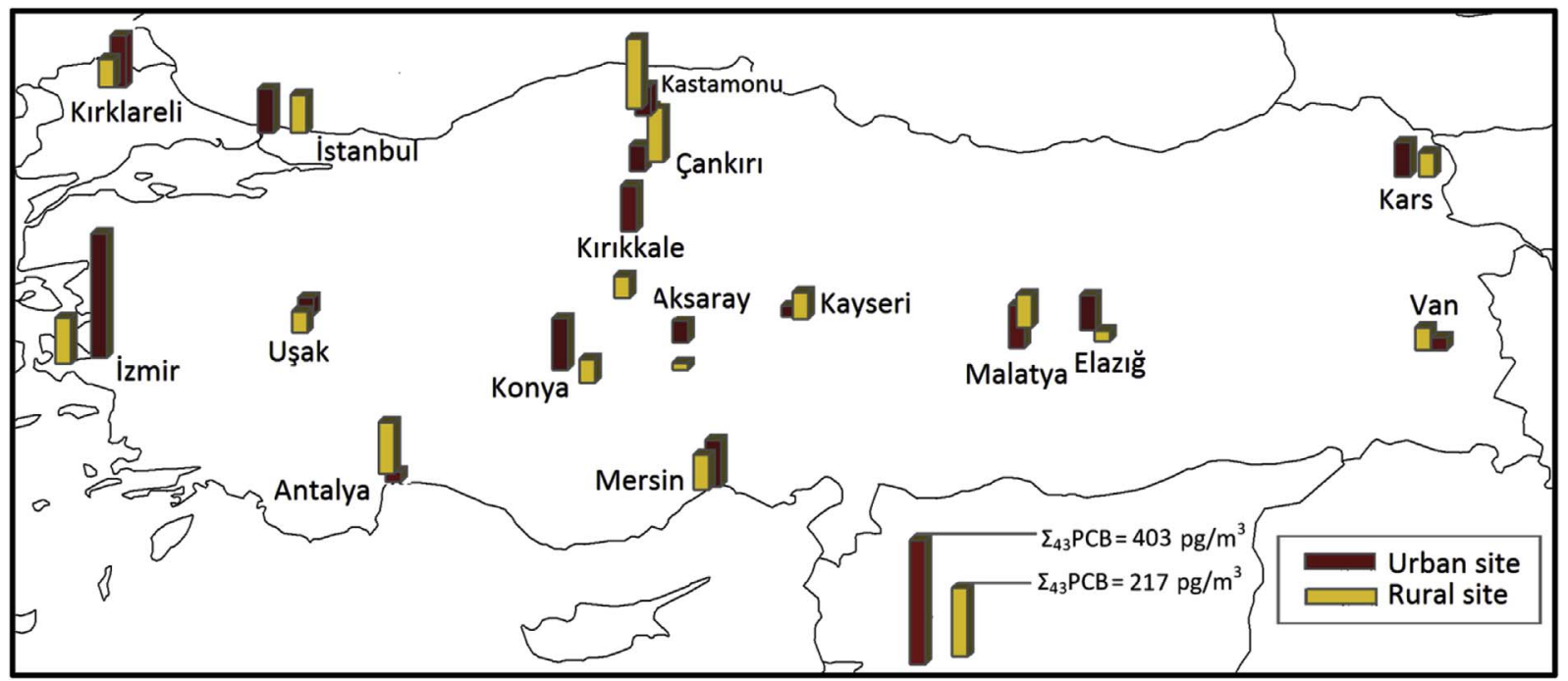

Fig. 1. Spatial variation in concentrations of $\Sigma_{43}$ PCBs.

trace organic analysis), and neutral alumina (90 active neutral, 0.063-0.2 mm particulate size) were purchased from Merck (Merck EMD Millipore, USA). Origins of recovery surrogate $\left({ }^{13} \mathrm{C}_{12}\right.$ - PCB-28, $-52,-101,-138,-153,-180$ and -209 ), depuration compounds and target chemicals are given in Supplementary Material Table S2.

\subsection{Sampler preparation and deployment}

Polyurethane foam (PUF) disks $(14 \mathrm{~cm}$ diameter; $1.35 \mathrm{~cm}$ thick; surface area, $365 \mathrm{~cm}^{2}$; mass, $4.40 \mathrm{~g}$; volume, $207 \mathrm{~cm}^{3}$; density, $0.0213 \mathrm{~g} / \mathrm{cm}^{3}$; Tisch Environmental, Cleaves, Ohio, USA) were used as passive sampling medium. PUF disks were spiked with depuration compounds $\left({ }^{13} \mathrm{C}_{12}\right.$ PCBs and native PCBs: $250 \mathrm{ng}$ each, $\mathrm{d}_{6-\gamma} \gamma-\mathrm{HCH}$ : $500 \mathrm{ng}$ ) prior to deployment since such compounds enable to measure sample volumes directly (Ockenden et al., 2001) whereas the rate of uptake of chemicals will be the same as the rate of loss of depuration compounds (Pozo et al., 2009; He and Balasubramanian, 2010). PUF disks were placed in stainless steel chambers at the sampling locations to prevent contamination by particle deposition, UV sunlight, and to minimize the effects of wind speed on the sampling rate (Tuduri et al., 2006). Further details on sampler preparation are given in Supplementary Material Table S3.

\subsection{Extraction}

PUF disks were spiked with recovery surrogate chemicals (50 ng each) prior to extraction and were subjected to Soxhlet extraction for $18 \mathrm{~h}$ using 1:1 acetone:hexane mixture. After extraction, volume was reduced to $2 \mathrm{ml}$ on a rotary evaporator, and was further concentrated to $0.5 \mathrm{ml}$ in isooctane under a gentle $\mathrm{N}_{2}$ stream. $6 \%$ deactivated alumina was used for clean-up of samples. Elution was done using $35 \mathrm{~mL}$ of $20 \%$ dichloromethane (DCM) in hexane. Final volume was $1 \mathrm{~mL}$ in isooctane and all extracts were spiked with internal standard $\left(50 \mathrm{ng}\right.$ of ${ }^{13} \mathrm{C}_{12} \mathrm{PCB}-$ 105) before instrumental analysis. Further details are given in Supplementary Material Table S3.

\subsection{Instrumental analysis}

Analysis of PCB congeners was conducted on a GC (Agilent 7890B) coupled with an MSD (Agilent 5977 MSD) operated on EI (electron impact)-selective ion monitoring (SIM) mode. Separation of PCB congeners was performed on a capillary DB- 5 column $(60 \mathrm{~m}, 0.25 \mathrm{~mm}$ i.d., $0.25 \mu \mathrm{m}$ film thickness, J\&W Scientific) (co-eluting congeners (PCB-41/ 64 and PCB-90/101)) were quantified together. Analysis of OCPs and PBDEs were conducted on the same instrument operated on NCI (negative chemical ionization)-selective ion monitoring (SIM) mode.
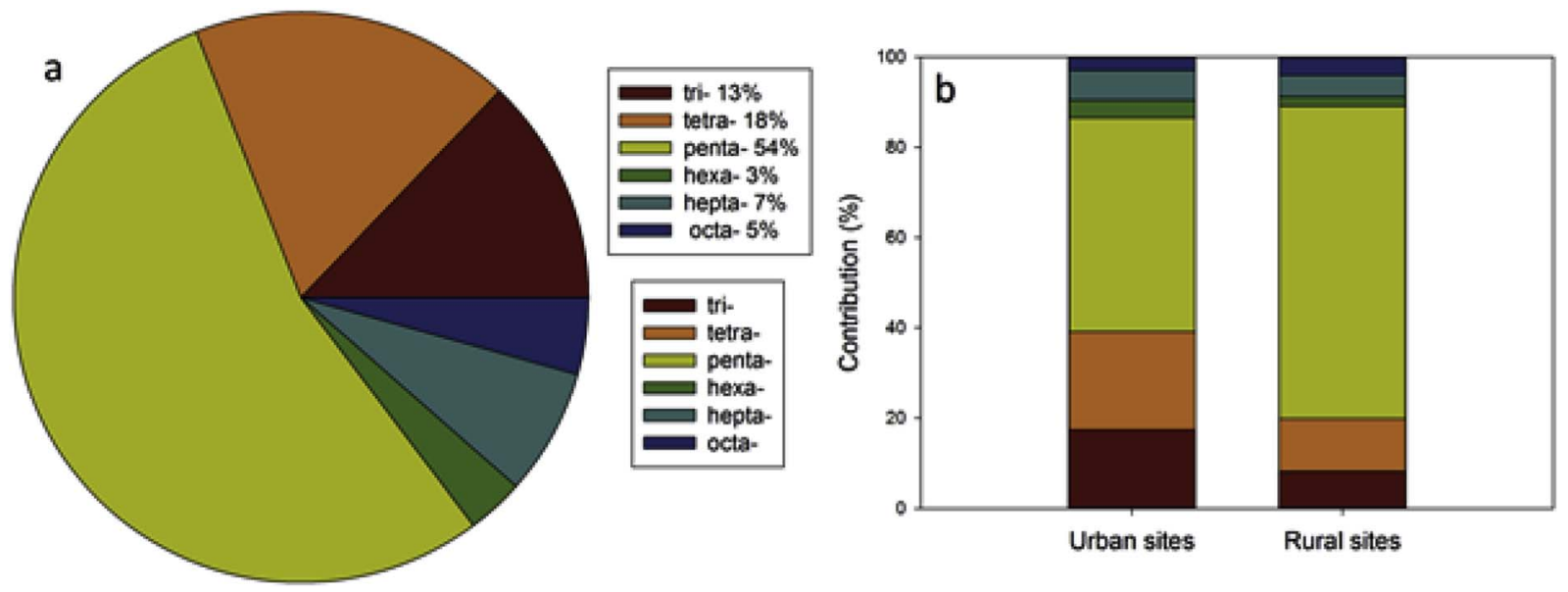

Fig. 2. Percent contribution of $P C B$ homologue groups to the total concentration (a) one-year average, (b) urban and rural sites. 


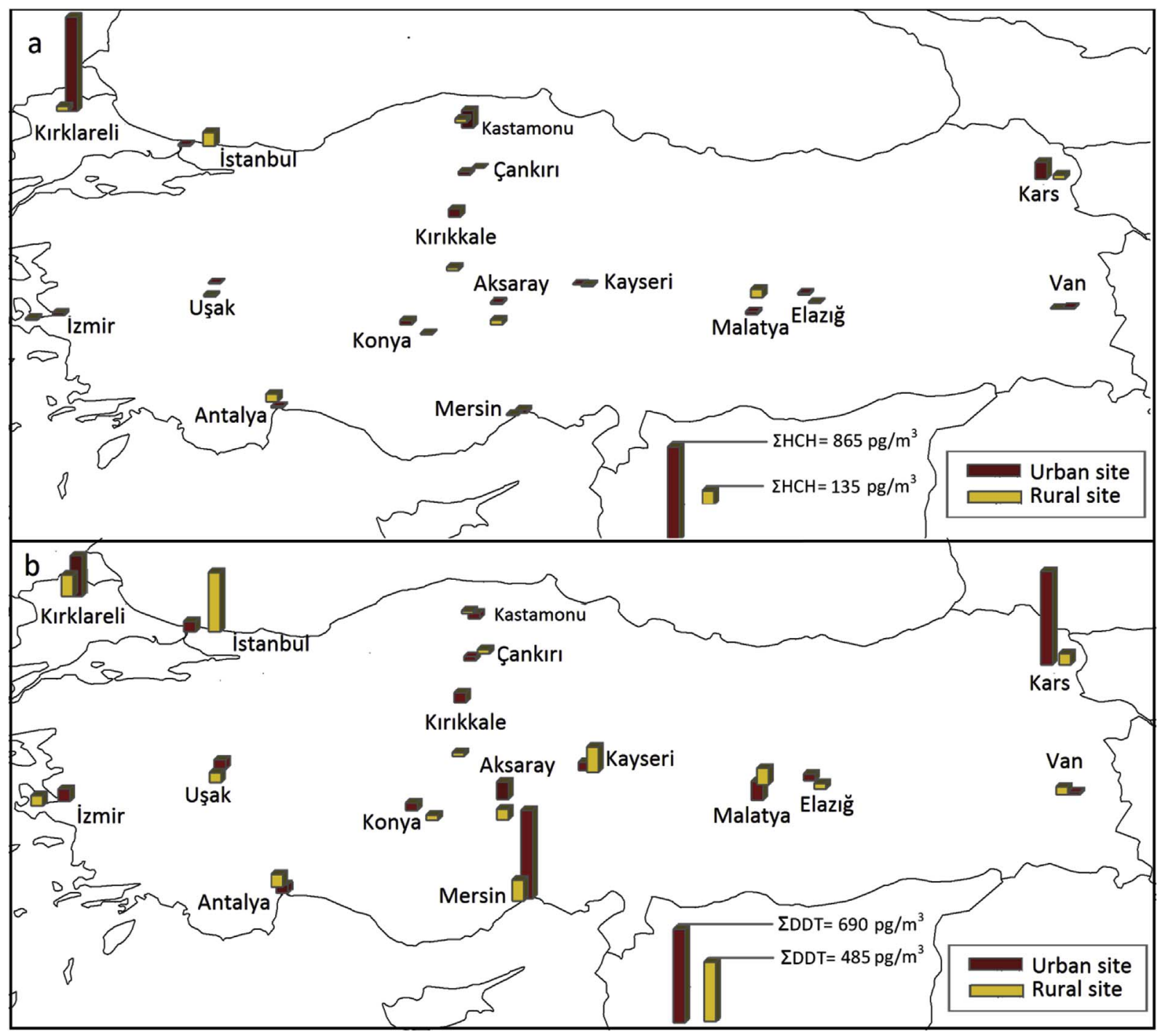

Fig. 3. Spatial variation in concentrations of (a) $\Sigma$ HCHs and (b) $\Sigma$ DDTs.

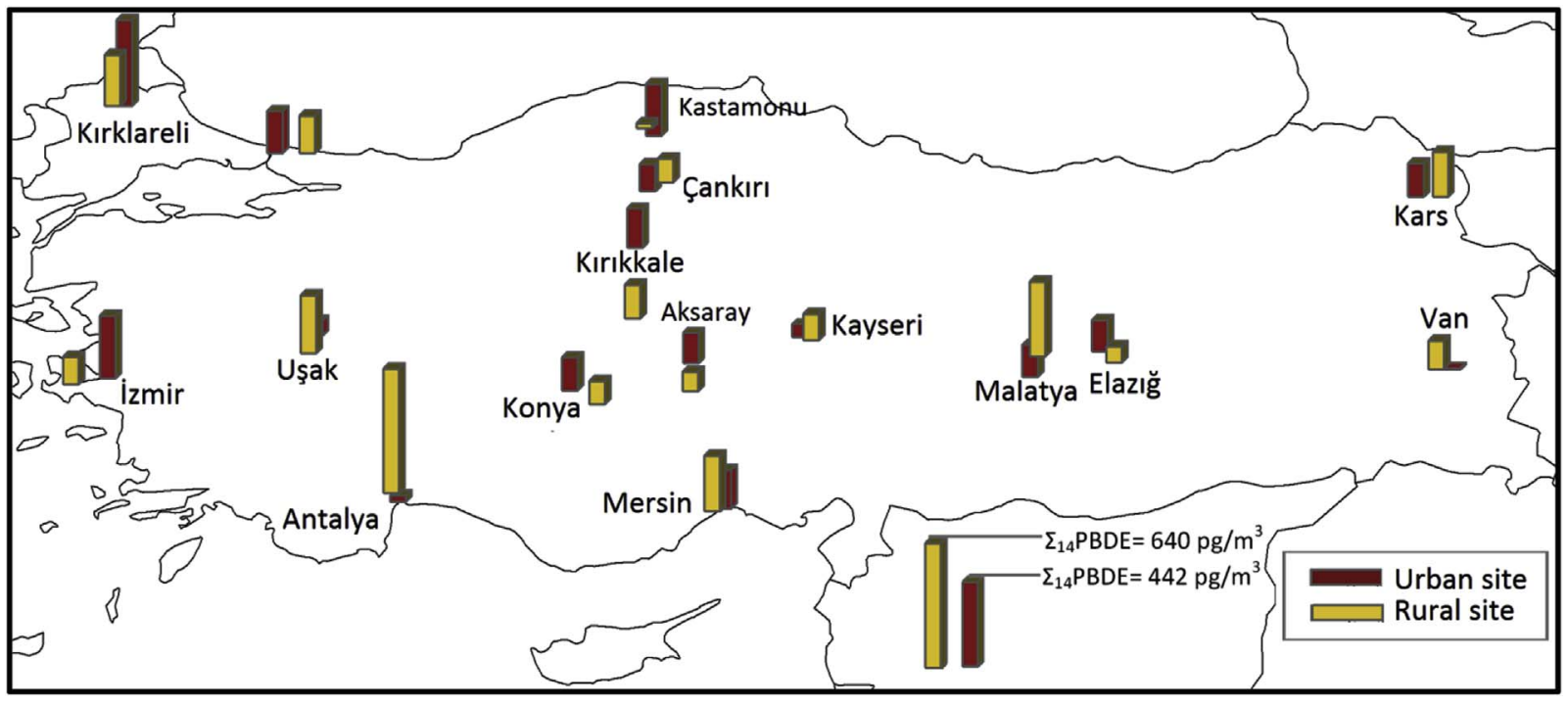

Fig. 4. Spatial variation of $\Sigma_{14}$ PBDEs. 
Separation of OCPs and PBDEs were performed together on a capillary DB-5 column ( $15 \mathrm{~m}, 0.25 \mathrm{~mm}$ i.d., $0.1 \mu \mathrm{m}$ film thickness). Details on instrument operating conditions and temperature program are given in Supplementary Material Table S4.

\subsection{Quality assurance (QA)/Quality control (QC)}

QA/QC measures included baking all glassware at $450{ }^{\circ} \mathrm{C}$ and solvent-rinsing before use, running laboratory and field blanks, calculating method detection limit (MDL) and instrument detection limit (IDL), analysis of an NIST-SRM dust for PBDEs, and calculating percent recovery of ${ }^{13} \mathrm{C}$-labelled surrogate compounds as well as calculating percent recovery of target chemicals via spiked samples. Method detection limit (MDL) and instrument detection limit (IDL) were calculated as follows: MDL = average concentration of target chemical in blank $+3 *$ std dev; IDL $=$ lowest calibration level produced a signal that is distinguishable from a reagent blank at a $3: 1 \mathrm{~S} / \mathrm{N}$ ratio; and IDL $=$ MDL (if analyte is not present in blank sample) (WDNRL, 1996). If any analyte was $<\mathrm{MDL}$, then concentration of that analyte was taken as $1 / 2$ of MDL of corresponding congener/chemical for statistical calculations. MDLs ranged from 1.83 to $8.85 \mathrm{pg} / \mathrm{m}^{3}$ for individual PCBs, $1.01-4.84 \mathrm{pg} / \mathrm{m}^{3}$ for individual PBDEs, and $2.32-5.40 \mathrm{pg} / \mathrm{m}^{3}$ for OCPs. A full list of MDLs for target chemicals are given in Supplementary Material Table S5. The amounts of targeted POPs were negligible in the field blanks relative to the samples $(<5 \%)$.

Procedural recovery efficiencies for PCB-spiked samples $(n=6)$ were in the range of $65 \%$ (PCB-153) to $100 \%$ (PCB-138) with the average of $80.5 \%$. Average procedural recovery efficiency of spiked OCPs $(n=6)$ and spiked PBDEs $(n=6)$ were $78 \%\left(64 \%, p\right.$, $p^{\prime}$-DDD $103 \%$, endrin) and 80\% (69\%, PBDE-28 - 94\%, PBDE-138), respectively. Average recovery efficiencies (\%) of the ${ }^{13} \mathrm{C}$ labelled surrogate compounds $(\mathrm{n}=209)$ was $83.4 \pm 16(61.3-134.4), 89.3 \pm 18.3$ (60.4-135), $\quad 86 \pm 13.6 \quad(61-121.4), \quad 86.8 .4 \pm 11 \quad(60.6-122)$, $91.5 \pm 11.8$ (60.6-131.2), $89.7 \pm 17$ (58.8-124) for ${ }^{13} \mathrm{C}_{12}$ PCB-28,$52,-101,-138,-153,-180$, and PCB-209, respectively. In the current study, only ${ }^{13} \mathrm{C}$-labelled PCBs were used as recovery surrogate compounds. However, in a similar study conducted in our laboratory using the same analytical and instrumental method, samples $(n=22)$ were spiked with $25 \mathrm{ng}$ of PBDE-77 and recovery efficiency was ranged between $66.10 \%$ and $117.6 \%$ with a mean value of $92.9 \pm 13.3 \%$. Moreover, in order to assess recovery efficiency of PBDEs replicate analysis of NIST SRM $2583(n=5)$ (National Institute of Standards Technology, MD, USA) was conducted, and results showed that relative standard deviations of replicate analysis of individual PBDE congeners of interest ranged between $8.1 \%$ (BDE-47; $278 \mathrm{ng} / \mathrm{g}-330 \mathrm{ng} / \mathrm{g}$ ) and $22.3 \%$ (BDE-154; $61 \mathrm{ng} / \mathrm{g}-108 \mathrm{ng} / \mathrm{g}$ ) with an average of $16.3 \%$. Concentrations of PBDE congeners in SRM 2583 was reported by Stapleton et al. (2006). Percent recovery of PBDE congeners in the current study compared to concentrations reported by Stapleton et al. (2006) were 108\%, 95\%, 94\%, 103\%, 102\%, 87\%, 90\%, 95\%, 105\%, $86 \%, 123 \%$, and $115 \%$ for BDE- $17,-28,-47,-66,-85,-99,-100$, $-138,-153,-154,-183$, and -209 , respectively. Relative standard deviations of detected concentrations of target PBDE congeners in SRM 2583 from concentrations reported by Stapleton et al. (2006) were ranged between 2.1 and $22.3 \%$ with an average deviation of $9.1 \%$. Details on results of this analysis are given elsewhere (Kurt-Karakus et al., 2017). Field blanks were prepared by exposing a PUF disk to air for about $10 \mathrm{~s}$ at the selected sampling points $(\mathrm{n}=12)$ and subjecting to the same sample preparation procedure as samples.

\subsection{Deriving air concentrations by depuration compounds}

Concentrations of target congeners in gas phase in air were derived from the chemical amount accumulated in PUF disk (ng/sampler) divided by the effective air volume $\left(\mathrm{V}_{\mathrm{AIR}}, \mathrm{m}^{3}\right)$. Site-specific effective air volume $\left(\mathrm{V}_{\mathrm{AIR}}\right)$ which is based on site specific linear phase sampling rates ( $R_{\text {sampling }} ; \mathrm{m}^{3} /$ day) was calculated using the equation proposed by Shoeib and Harner (2002). Air volume sampled by PUF-PAS was calculated using data on the loss of depuration compounds (Pozo et al., 2004; Gouin et al., 2005) and GAPS (Global Atmospheric Passive Sampling) template (Harner, 2016; Parnis et al., 2016). Average R value was $6.34 \pm 2.74 \mathrm{~m}^{3} /$ day (Phase I: $2.04-5.53 \mathrm{~m}^{3} /$ day; Phase II: $5.61-12.15 \mathrm{~m}^{3} /$ day; Phase III: $1.18-7.91 \mathrm{~m}^{3} /$ day; Phase IV: $2.64-8.69 \mathrm{~m}^{3}$ /day) where the differences might have occurred based on meteorological conditions (Tuduri et al., 2006; Klánová et al., 2008).

\subsection{Statistical analysis}

Concentration data of PCBs, PBDEs and OCPs showed non-normal distributions. Therefore, Mann-Whitney $U$ test was used to compare the medians of two independent samples (median pollutant concentrations of urban and rural sites) and to investigate seasonal variation in pollutant concentrations through comparing the samples collected at higher (range: $14.4-25.6{ }^{\circ} \mathrm{C}$ ) and lower (range: -3.6-14.1 ${ }^{\circ} \mathrm{C}$ ) than average $\left(14.2^{\circ} \mathrm{C}\right)$ temperatures over the one-year sampling period. The test was performed by Minitab v16 software. Comparison of data from the current study to results of other studies in Turkey and other regions of the world was based on average concentrations.

Factor analysis was used to analyze if variation in levels of 21 OCPs (except $o, p$ '-DDD because it was not detected), 43 PCBs, and 14 PBDEs could be represented with a less number of components. It was expected that the factors would cover the compounds with similar variations originated from similar sources. Therefore, it could be used as a receptor oriented apportionment tool. The analysis was performed using SPSS software (v4). Varimax rotated principal component analysis was used. Eigen values of $>1$ and loadings of $>0.5$ were regarded as significant for interpretation of factors.

\section{Results and discussion}

\subsection{Ambient air concentrations of targeted POPS}

\subsection{1. $P C B s$}

Annual average concentration of $\Sigma_{43} \mathrm{PCBs}$ was $108 \pm 132 \mathrm{pg} / \mathrm{m}^{3}$. Kayseri $\left(14.5 \pm 14.3 \mathrm{pg} / \mathrm{m}^{3}\right)$ and Izmir $\left(403 \pm 428 \mathrm{pg} / \mathrm{m}^{3}\right)$ showed the lowest and the highest mean $\Sigma_{43}$ PCBs concentration at urban sites. At rural sites, mean concentration in Aksaray $\left(19.0 \pm 22.7 \mathrm{pg} / \mathrm{m}^{3}\right)$ was the lowest while Kastamonu $\left(217 \pm 353 \mathrm{pg} / \mathrm{m}^{3}\right)$ showed the highest levels of $\Sigma_{43}$ PCBs (Fig. 1). In addition to the probable urban sources, the higher concentrations detected in Izmir may be related to emissions from the close-by Aliaga industrial area such as from ferrous scrap processing steel plants with electric arc furnaces (Odabasi et al., 2009, 2017). Actually, $\Sigma_{43}$ PCB concentration detected $50 \mathrm{~km}$ West of Izmir at Urla was the second highest among the 41 sites around the globe (Pozo et al., 2006), and the second highest ( $\Sigma_{7}$ indicator PCBs) after Thessaloniki, Greece among the 10 sites around the Aegean (Lammel et al., 2015). Pozo et al. (2012) measured concentrations of $\Sigma_{43}$ PCBs at urban sites $\left(16 \mathrm{pg} / \mathrm{m}^{3}\right)$ and rural sites $\left(40 \mathrm{pg} / \mathrm{m}^{3}\right)$ in Chile from January to March 2007. Annual average concentration of $\Sigma_{43}$ PCBs detected in this study was in the range of $\Sigma_{41}$ PCBs reported in air in Kutahya (19.6-675.1 pg/m³) (Dumanoglu et al., 2017).

In GAPS study, levels in urban sites were higher than those of suburban sites (Pozo et al., 2006). In a study in Chile, concentrations measured at urban sites were on average 1.2 times higher than those of rural sites, although not significantly different statistically $(\mathrm{p}>.05)$, in agreement with the GAPS study.

The congener with the highest annual average among the targeted PCBs was PCB-118 with a value of $26.3 \pm 44.6 \mathrm{pg} / \mathrm{m}^{3}$. PCB-54, PCB156, and PCB-188 were not detected in the samples. PCB-104, PCB-114, PCB-118, PCB-123, PCB-151, PCB-167, and PCB-203 had higher mean concentrations at rural sites compared to urban sites. However, median concentrations of the targeted PCBs at urban sites were not significantly 
different than those measured at rural sites $(p>.05)$. Low to medium molecular weight congeners (PCB-18, $-17,-31,-28,-33,-52$, $-44,-70$, and -101 ) were dominant in ambient air of Aliaga (Odabasi et al., 2015). In this study PCB-101, -138 and -153 and -118 were higher at urban sites as opposed to the case in Azerbaijan (Aliyeva et al., 2012) where only PCB118 was higher in urban sites. Annual average contributions of homologue groups tri-to octa-CBs to the concentration are shown in Fig. 2a. The groups from the highest to lowest contributions were penta-CBs $>$ tetra-CBs $>$ tri-CBs $>$ hepta$\mathrm{CBs}>$ octa-CBs $>$ hexa-CBs. Dominance of lower $\mathrm{Cl}$ content $(\leq \%$ $5 \mathrm{Cl}$ ) PCBs was observed in industrial, rural and urban (Zhang et al., 2008) areas. Birgul et al. (2017) reported that PCB profile at all sampling sites was dominated by 4-Cl PCBs in a study conducted in Bursa province in Turkey. In a study conducted by Kaya et al. (2012), low molecular weight congeners (3- and 4-Cl) dominated the $\Sigma_{41}$ PCB concentrations in Aliaga industrial region in Turkey. Bozlaker et al. (2008) also reported dominance of 3-Cl to 5-Cl PCBs in Aliaga industrial region of the country. Cindoruk et al. (2007) reported that PCBs were often found as 3-Cl and 4-Cl (65.7\% and 25.1\%) for BOID (Bursa Organised Industrial District) site of Bursa. Low molecular weight congeners (PCB$17,18,28,31,33,44,49$, and 52) dominated the $\Sigma_{41}$ PCB concentrations reported in Kutahya ambient air by Dumanoglu et al. (2017).

Composition of PCB mixtures, partitioning, vapor pressure, and water solubility are the significant parameters effecting contribution of the groups (ATSDR, 2000). Besides, tri- and tetra-CBs may travel long distances because they are lighter than other groups (penta-, hexa-, hepta-, and octa-CBs) before depositing on the soil. Elevated penta-CB contribution was consistent with the results of Du et al. (2009) performed in Philadelphia metropolitan area. As a general view, the contribution of less chlorinated homologue groups (tri-, tetra, and pentaCBs) were higher compared to those with higher number of chlorine atoms (hexa-, hepta-, and octa-CBs) because increasing number of chlorine atom decreases vapor pressure and water solubility. Therefore, PCB homologue groups $\leq$ penta-CBs tend to be in gas phase and dissolve in water thereby increasing the possibility of detection in the atmosphere (Yeo et al., 2003) but others tend to deposit on different surfaces. Low-molecular weight congeners were mostly found to be higher at background sites, whereas those with high molecular weight were detected at suburban and urban sites (Du et al., 2009). In contrast, not only the urban sites but also rural sites were dominated by pentaCBs in this study, whereas the lighter groups (such as tri- and tetra-CBs) had lower percentages at the rural sites (Fig. 2b), which may be associated with legacy uses of Aroclors in building materials and modern PCB containing paint and consumer products, light ballasts, sealants, and window caulking (Marek et al., 2017, and references therein).

Since the decision related to the ban of PCB utilization in 1996 was published in 1993 in the official gazette in Turkey (Official Gazette, 1993), long range transport from places with considerable point sources and volatilization from deposited surfaces can be the potential origin of PCBs (Cleverly et al., 2007; Wania et al., 2003). On the other hand, Gedik and Imamoglu (2010) reported imported amounts of PCBs from producer (Germany, France, Italy and Spain) and non-producer (Belgium-Luxembourg, Ireland and Austria) countries to Turkey between 1996 and 2003 (which corresponds to a period after the ban on PCBs utilization) and total imported PCBs amounted to be about $95000 \mathrm{~kg}$. A partially successful inventory study revealed the presence of a total of 6 capacitors and 189 transformers containing PCBs were present in the country in 2006 (Acara, 2006), while the updated National Implementation Plan (NIP) of the country reported that identification of a total of 290 transformers and 1972 capacitors containing PCBs were identified (Acara, 2008). As mentioned by Gedik and Imamoglu (2010), part of this equipment was still in use while others were stored for disposal in the future. Erickson and Kaley (2011) states that one of the most important sources can be electronic wastes because PCBs were extensively used in transformers, capacitors, and heat transfer fluid in the past. Therefore, places where e-wastes were processed, PCB- contaminated equipment storage areas and/or landfills might be significant sources of contamination.

\subsubsection{OCPs}

OCPs investigated in this study were used in the past to prevent, control or destroy insects and diseases causing harmful effects on plants and animals. Volatilization from agricultural soils contaminated by OCPs in the past are the main sources to air (Aliyeva et al., 2012; Cindoruk, 2011; Odabasi and Cetin, 2012; Pozo et al., 2011). The mean concentrations ranked as इDDT (p,p'-DDE, o,p'-DDE, p,p'-DDT, o,p'-DDT, p,p'-DDD) (134 pg/ $\left.\mathrm{m}^{3}\right)>\Sigma \mathrm{HCH}\left(\alpha+\beta+\gamma+\delta\right.$-isomers) $\left(64.4 \mathrm{pg} / \mathrm{m}^{3}\right)>\mathrm{HCB}(45.1 \mathrm{pg} /$ $\left.\mathrm{m}^{3}\right)>\Sigma$ endrin + dieldrin $\left(30.4 \mathrm{pg} / \mathrm{m}^{3}\right)>$ Eendosulfan $\left(\alpha-, \beta-,-S O_{4}\right)$ $\left(27.2 \mathrm{pg} / \mathrm{m}^{3}\right)>$ Sheptachlor + heptachlorepoxide $\left(24.1 \mathrm{pg} / \mathrm{m}^{3}\right)>$ Mirex $\left(13.4 \mathrm{pg} / \mathrm{m}^{3}\right)>$ Echlordane (cis- + trans-chlordane) $\left(2.14 \mathrm{pg} / \mathrm{m}^{3}\right)$. o,p'DDD was not detected in the samples but $\Sigma$ DDT was the pollutant group with the highest average concentration. $\Sigma \mathrm{HCH}, \mathrm{HCB}, \Sigma \mathrm{DDT}$, and $\Sigma$ endosulfan were the groups that are generally found to be higher at urban sites than rural sites among the listed groups.

HCHs have different mixtures such that technical $\mathrm{HCH}$ is a mixture rich in $\alpha$-isomer ( $\alpha$ : 55-80\%, $\beta$ : 5-14\%, $\gamma: 8-15 \%, \delta: 2-16 \% \varepsilon$ : $3-5 \%$ ) whereas $\gamma$-isomer (>90\%) dominates lindane (Vijgen et al., 2006). Lindane was one of the compounds forbidden in 1979 in Turkey (Ahioğlu, 2008). The annual average $\mathrm{\Sigma HCH}$ concentration $\left(64.5 \pm 288 \mathrm{pg} / \mathrm{m}^{3}\right)$ comprised $19.1 \%$ of the total OCP level, with a range of $<$ MDL (Van) to $867 \mathrm{pg} / \mathrm{m}^{3}$ (Kirklareli) at the urban sites, and of $4.45 \mathrm{pg} / \mathrm{m}^{3}$ (Çankıri) to $134 \mathrm{pg} / \mathrm{m}^{3}$ (İstanbul) at the rural sites (Fig. 3a). The annual average at the urban sites $\left(93.6 \pm 397 \mathrm{pg} / \mathrm{m}^{3}\right)$ were 2.5 times higher than those of rural sites $\left(35.1 \pm 73.1 \mathrm{pg} / \mathrm{m}^{3}\right)$ but the difference was not significant statistically $(p>.05)$. The dominating $\mathrm{HCH}$ isomers were $\alpha-\left(22.0 \pm 92.8 \mathrm{pg} / \mathrm{m}^{3}\right)$ and $\beta$ $\left(21.8 \pm 96.1 \mathrm{pg} / \mathrm{m}^{3}\right)$. The average concentrations of $\gamma$ - and $\delta$-isomers were $7.34 \pm 45.7 \mathrm{pg} / \mathrm{m}^{3}$ and $13.4 \pm 86.8 \mathrm{pg} / \mathrm{m}^{3}$, respectively (Supplementary Material, Fig. S1a). $\beta-\mathrm{HCH}$ was also dominating $\mathrm{HCH}$ isomer in Bursa (Esen, 2013; Cindoruk and Tasdemir, 2014) whereas $\alpha$ $\mathrm{HCH}$ was also the dominating isomer in the studies of Aliyeva et al. (2012) and Devi et al. (2011). The mean $\alpha-\mathrm{HCH} / \gamma-\mathrm{HCH}$ ratios for urban and rural sites were 2.26 and 7.68, respectively. The ratios between 4 and 7 might show that atmospheric concentrations were affected from usage of technical-HCH, while $<4$ might indicate that levels were under the mixed influence of lindane and technical-HCH utilization (Su et al., 2006). The ratio for the rural sites was $>7$ probably because $\gamma$ $\mathrm{HCH}$ has a lower residence time in the atmosphere due to high reaction rate of hydroxyl radicals with $\gamma$-isomer and lower Henry's Law constant than $\alpha$-isomer (Brubaker and Hites, 1998).

Production and sale of DDT was prohibited in 1978 and 1985 in Turkey, respectively (Ahioğlu, 2008). $\Sigma$ DDT concentrations varied from $12.5 \pm 15.6$ to $686 \pm 754 \mathrm{pg} / \mathrm{m}^{3}$ at the urban sites and from $11.7 \pm 8.62$ to $484 \pm 789 \mathrm{pg} / \mathrm{m}^{3}$ at the rural sites. The spatial variation of $\Sigma D D T$ is shown in Fig. 3b. Érseková et al. (2014) indicated that the highest levels of $\Sigma$ DDTs was detected from March to August 2006 at urban sites of Serbia $\left(986 \mathrm{pg} / \mathrm{m}^{3}\right)$ and Romania $\left(448 \mathrm{pg} / \mathrm{m}^{3}\right)$, and rural site of Romania $\left(330 \mathrm{pg} / \mathrm{m}^{3}\right.$ ) with the mean of $295 \mathrm{pg} / \mathrm{m}^{3}$ that was 2.1 folds higher than the mean calculated in this study $\left(134 \pm 296 \mathrm{pg} / \mathrm{m}^{3}\right) \cdot p, p^{\prime}$-DDE had the highest mean level among the listed isomers for all sampling periods similar to measured values in the Czech Republic (Klánová et al., 2006) whereas o,p'-DDD was not detected as in the GAPS study (Pozo et al., 2006) (Supplementary Material, Fig. S1b). Since $p, p^{\prime}$-DDT is converted to $p, p$ '-DDE by UV radiation during atmospheric transport, concentration of $p, p$ '-DDE could be elevated due to this (Atlas and Giam, 1988). Furthermore, volatilization of DDD and DDE formed from decomposition of DDT in the soil by microorganisms may be another source (ATSDR, 2002). p,p'-DDT contributed $16 \%$ of $\Sigma$ DDT in this study compared to $12 \%$ in the study conducted at urban, rural, and wetland areas of India (Zhang et al., 2008). Contribution of $p$, $p^{\prime}$-DDT to $\Sigma$ DDT was $54 \%$ in the non-heating period and $38 \%$ in the heating period in Izmir (Ugranli et al., 2016). 
The mean concentrations of all isomers were found to be higher at urban sites. Mean $p, p^{\prime}$-DDE/p, $p^{\prime}$-DDT ratios were greater than 1 at urban (5.21) and rural sites (3.80) implying aged usage of DDT in Turkey similar to that in Azerbaijan (Aliyeva et al., 2012). This ratio was found as 0.73 in the non-heating period and 1.51 in the heating period in a suburban area in Izmir (Ugranli et al., 2016).

The mean concentration of इendosulfan at the urban sites $\left(35.0 \pm 83.2 \mathrm{pg} / \mathrm{m}^{3}\right)$ was higher than that of the rural sites $\left(19.4 \pm 39.2 \mathrm{pg} / \mathrm{m}^{3}\right.$ ). Endo-SO ${ }_{4}$ was the least detected isomer (only 2 times out of 128 samples) with the average of $0.57 \pm 4.74 \mathrm{pg} / \mathrm{m}^{3}$. The mean $\beta$ endosulfan $\left(15.2 \pm 59.8 \mathrm{pg} / \mathrm{m}^{3}\right)$ level was higher than $\alpha$-endosulfan $\left(11.5 \pm 12.5 \mathrm{pg} / \mathrm{m}^{3}\right)$. In spite of the fact that the urban sites were dominated by $\beta$-endosulfan ( $\alpha$-endosulfan: $12.4 \pm 13.8 \mathrm{pg} / \mathrm{m}^{3}, \beta$-endosulfan: $22.8 \pm 79.2 \mathrm{pg} / \mathrm{m}^{3}$ ), their levels were similar at the rural sites ( $\alpha$-endosulfan: $10.6 \pm 10.9 \mathrm{pg} / \mathrm{m}^{3}, \beta$-endosulfan: $7.75 \pm 28.2 \mathrm{pg} / \mathrm{m}^{3}$ ). $\alpha$-endosulfan/ $\beta$-endosulfan ratio for urban sites was 0.55 but it was 1.38 for rural sites. $\alpha$-endosulfan is mostly found in elevated levels at agricultural sites in the literature (such as olives, sunflower, and vineyards) (Estellano et al., 2012). Therefore, it is reasonable that rural sites had higher $\alpha$-endosulfan from local application. Global concentrations (Weber et al., 2010 and references therein) along with those measured in Turkey (such as by Odabasi et al. (2008) and Ugranli et al. (2016)) reflect endosulfan levels during it was in use. However, the profile since its ban may be in the process of shifting from $\alpha$-to $\beta$-isomer due to differences in the degradation rates in soil, which depend on type of soil in terms of biological activity (Bussian et al., 2015). Furthermore, the turnover may also occur during LRAT as the travel distances increase from application sites where it is still in use (Carrera et al., 2002; Weber et al., 2010). In fact, there are reports of $\alpha$ / $\beta<1$ (Schrlau et al., 2011; Wang et al., 2014) including from Turkey, urban Bursa where it was 0.61 and 0.86 at two sites (Cindoruk, 2011 and personal communication). Nevertheless, the observation of $\alpha / \beta<1$ in this study is based on the whole dataset which contains high $\beta$-isomer concentrations at Malatya $\left(127 \mathrm{pg} / \mathrm{m}^{3}\right)$ and Mersin $\left(139 \mathrm{pg} / \mathrm{m}^{3}\right)$ in Period-I, and very high concentrations at Istanbul $\left(221 \mathrm{pg} / \mathrm{m}^{3}\right)$ and Kars $(609 \mathrm{pg} / \mathrm{m} 3)$ in Period-II. If these four data points are not considered, $\alpha / \beta$ ratio retreats to a value (1.64) in line with the majority of the literature.

The annual average concentration of $\Sigma$ heptachlor was measured as $24.3 \pm 159 \mathrm{pg} / \mathrm{m}^{3}$. An extremely large value was detected at the urban site of Kirklareli $\left(1758 \mathrm{pg} / \mathrm{m}^{3}\right)$ so the mean level of this site is much greater than the other locations. The annual mean level of $\Sigma$ heptachlor at the urban sites varied from $<$ MDL to $458 \pm 867 \mathrm{pg} / \mathrm{m}^{3}$ (mean: $35.2 \pm 218 \mathrm{pg} / \mathrm{m}^{3}$ ), whereas average concentrations were in the range of $<$ MDL to $103 \pm 191 \mathrm{pg} / \mathrm{m}^{3}$ (mean: $13.2 \pm 50.0 \mathrm{pg} / \mathrm{m}^{3}$ ) at the rural sites. One-year average concentrations at urban sites (except Kirklareli) and rural sites (except İstanbul) were $<30 \mathrm{pg} / \mathrm{m}^{3}$. Mean heptachlor epoxide concentrations for both urban $(29.3 \pm 2188 \mathrm{pg} /$ $\left.\mathrm{m}^{3}\right)$ and rural sites $\left(8.50 \pm 48.9 \mathrm{pg} / \mathrm{m}^{3}\right)$ were greater than heptachlor levels measured at urban $\left(5.89 \pm 14.9 \mathrm{pg} / \mathrm{m}^{3}\right)$ and rural sites $\left(4.74 \pm 13.7 \mathrm{pg} / \mathrm{m}^{3}\right)$. Annual average concentration of chlordane (TC + CC) was very low (average: $2.15 \pm 13.3 \mathrm{pg} / \mathrm{m}^{3}$ ) and found only 9 out of 128 samples. Average level of chlordane was $3.44 \pm 17.8 \mathrm{pg} /$ $\mathrm{m}^{3}$ (maximum: $137 \mathrm{pg} / \mathrm{m}^{3}$ ) at urban sites and $0.85 \pm 5.76 \mathrm{pg} / \mathrm{m}^{3}$ (maximum: $44.2 \mathrm{pg} / \mathrm{m}^{3}$ ) at rural sites. Mean level of CC and TC were $2.11 \pm 10.9 \mathrm{pg} / \mathrm{m}^{3}$ and $1.32 \pm 7.26 \mathrm{pg} / \mathrm{m}^{3}$ at urban sites and $0.46 \pm 2.56 \mathrm{pg} / \mathrm{m}^{3}$ and $0.39 \pm 3.09 \mathrm{pg} / \mathrm{m}^{3}$ at rural sites, respectively. Urban sites were enriched by TC with $61.4 \%$ of TC + CC average. The detection frequency of aldrin was only 2 out of 128 samples. Annual average level of Eendrin + aldrin + dieldrin was $30.4 \pm 121 \mathrm{pg} / \mathrm{m}^{3}$. The average concentrations at urban and rural sites were between $<$ MDL and $105 \pm 182 \mathrm{pg} / \mathrm{m}^{3}$, and between $<$ MDL and $366 \pm 617 \mathrm{pg} / \mathrm{m}^{3}$, respectively. Mean concentrations at urban and rural sites were $24.4 \pm 54.0 \mathrm{pg} / \mathrm{m}^{3}$ and $36.5 \pm 163 \mathrm{pg} / \mathrm{m}^{3}$, respectively. Dieldrin was found to be the dominant isomer for both urban and rural sites whereas the levels of aldrin were almost zero (Supplementary Material, Fig. S1c). Annual mean (urban + rural) of Mirex was found as $13.4 \pm 66.6 \mathrm{pg} / \mathrm{m}^{3}$ and the detection rate was 19 out of 128 samples.
The range of means was from $<$ MDL to $23.0 \pm 46.1 \mathrm{pg} / \mathrm{m}^{3}$ (average: $5.62 \pm 17.7 \mathrm{pg} / \mathrm{m}^{3}$ ) at urban sites and from < MDL to $176 \pm 352 \mathrm{pg} /$ $\mathrm{m}^{3}$ (average: $21.4 \pm 92.2 \mathrm{pg} / \mathrm{m}^{3}$ ) at rural sites. Since Mirex binds to soil particles or sediment in water, it does not volatilize to air easily (ATSDR, 1995), so this might be the reason for the low detection rate. Turgut et al. (2012) and Voigt et al. (2013) reported presence of Mirex in soil and all human milk samples collected from villages located on $0 \mathrm{~m}, 121 \mathrm{~m}, 408 \mathrm{~m}, 981 \mathrm{~m}, 1881 \mathrm{~m}$ altitudes of Taurus Mountains in southern Turkey. However, the main reason is most probably minimal LRAT (Turgut et al., 2012; Voigt et al., 2013) because it was not registered/used (Acara, 2008; Turgut et al., 2012; Voigt et al., 2013) in Turkey. Annual mean level of HCB was $45.3 \pm 197 \mathrm{pg} / \mathrm{m}^{3}$. The sampling locations with the lowest and highest mean levels were Çankırı and Kars among urban sites, and Antalya and İstanbul among rural sites. The annual mean levels measured at urban and rural sites were $57.7 \pm 230 \mathrm{pg} / \mathrm{m}^{3}$ and $32.8 \pm 157 \mathrm{pg} / \mathrm{m}^{3}$, respectively. Spatial variation graphs of OCPs are given in Supplementary Material (Figs. S2-S8).

Overall, extreme or high annual average concentrations of OCP groups were found in Kirklareli, Istanbul, and Kars, for which LRAT may be a possible explanation, because these locations are three of the four the most northern sites in this study, i.e., the area where air masses from the northerly direction arrive to the country. Dominant wind directions during the one-year sampling period were NNE for Istanbul and NE for Kars (Supplementary Material, Fig. S9). NNE is also the dominant wind direction in Kirklareli (Vardar and Eker, 2003). Hence, the results of this study may indicate that long range transport from the northerly directions are possible sources of OCP contamination.

\subsubsection{PBDEs}

PBDEs especially penta-, octa-, and deca-formulations have been widely used as flame retardants in computers, plastic products, textiles, and electronic equipment (Baek et al., 2008). PBDEs (penta-, octa-, and deca-BDEs) have recently been banned (Stockholm Convention, 2017). The overall annual average $\Sigma_{14} \mathrm{PBDE}$ concentration was found as $191 \pm 329 \mathrm{pg} / \mathrm{m}^{3}$. It was $183 \pm 260 \mathrm{pg} / \mathrm{m}^{3}$ and $200 \pm 387 \mathrm{pg} / \mathrm{m}^{3}$ for the urban and rural sites, respectively (Fig. 4). In the literature, PBDE congeners were reported to be $<$ MDL in all sampling sites in Brazil and Chile (Pozo et al., 2004, 2012; Meire et al., 2012). The highest annual mean levels were measured at Kirklareli among the urban sites and at Antalya among the rural sites in this study. Annual mean levels of BDE-17, $-28,-100,-153$, and -154 were $<0.5 \mathrm{pg} / \mathrm{m}^{3}$. BDE-190 (42\%), $-99(24.4 \%)$, and $-47(20.6 \%)$ had the three highest contributions to $\Sigma_{14} \mathrm{PBDEs}$. While other studies have indicated BDE-209 as the predominant congener, our results are not without precedent. Wang et al. (2010) reported that BDE-47 and -99 had the highest contributions with the range of $22-72 \%$ and $14-47 \%$, respectively in the Tibetan Plateau. Jaward et al. (2004) also found these compounds as the dominant contributors, contributing $75 \%$ to total BDEs. There is also a study from Turkey reporting a lower gas phase BDE-209 concentration (6.8 pg/ $\mathrm{m} 3$ ) compared to BDE-100 (9 pg/m3) and BDE-47 (8.2 pg/m3) (Cetin and Odabasi, 2007). BDE-47 and -99 are the main components of the commercial product, Bromkal $70-5 \mathrm{DE}$ with around $70-80 \%$ of the mixture (Sundström and Hutzinger, 1976; Sjödin et al., 1998). Atmospheric travel distance of BDE-47 is greater than BDE-99 (Wania and Dugani, 2003). Since contribution of BDE-99 was slightly higher than BDE-47, not only LRAT but also volatilization from sinks or formerly contaminated sites may be possible sources of these congeners. BDE-183, which is a major component of commercial octa-BDE (Stockholm Convention, 2008), was not detected in the samples and this suggests that the usage of octa-BDEs in Turkey and the affecting regions may be negligible.

\subsection{Seasonal variation}

The concentrations detected in four sampling periods at urban and rural sites are listed in Table 1 . Because there are differences between calendar and observed seasons among different regions of Turkey, the 
Table 1

Seasonal variation of targeted POPs at urban and rural sites $\left(\mathrm{pg} / \mathrm{m}^{3}\right)$.

\begin{tabular}{|c|c|c|c|c|c|c|c|c|c|c|c|c|c|c|}
\hline & & $\begin{array}{l}\mathrm{R} \\
\left(\mathrm{m}^{3} /\right. \\
\text { day })\end{array}$ & $\mathrm{T}\left({ }^{\circ} \mathrm{C}\right)$ & $\Sigma$ HCHs & HCB & ¿DDTs & $\Sigma$ ENDO & $\Sigma$ HEP & $\mathrm{TC}+\mathrm{CC}$ & $\Sigma$ ENDs & $\Sigma_{22} \mathrm{OCPs}$ & $\Sigma_{43} \mathrm{PCBs}$ & $\Sigma_{7} \mathrm{iPCB}$ & $\Sigma_{14} \mathrm{PBDEs}$ \\
\hline \multicolumn{15}{|l|}{ URBAN } \\
\hline \multirow[t]{14}{*}{$1^{\mathrm{ST}}$ PERIOD } & $\mathrm{n}^{*, \mathrm{a}}$ & & & 8 & 11 & 7 & 9 & 2 & 2 & 9 & 12 & 12 & 8 & 12 \\
\hline & Mean & 7.75 & 20.19 & 101 & 19.9 & 187 & 64.2 & 27.7 & 19.1 & 60.4 & 295.70 & 118.53 & 22.8 & 99.3 \\
\hline & $\mathrm{SD}$ & 1.44 & 3.80 & 211 & 10.2 & 278 & 57.4 & 5.88 & 16.7 & 44.0 & 291.96 & 80.89 & 15.0 & 103 \\
\hline & Min. $(* *)$ & 5.34 & 10.6 & $\begin{array}{l}<\mathrm{MDL} \\
(5.38)\end{array}$ & $\begin{array}{l}<\mathrm{MDL} \\
(9.80)\end{array}$ & $\begin{array}{l}<\mathrm{MDL} \\
(13.9)\end{array}$ & $\begin{array}{l}<\text { MDL } \\
(6.82)\end{array}$ & $\begin{array}{l}<\mathrm{MDL} \\
(23.5)\end{array}$ & $\begin{array}{l}<\mathrm{MDL} \\
(7.29)\end{array}$ & $\begin{array}{l}<\mathrm{MDL} \\
(14.6)\end{array}$ & $\begin{array}{c}<\mathrm{MDL} \\
(32.84)\end{array}$ & $\begin{array}{l}<\text { MDL } \\
(5.36)\end{array}$ & $\begin{array}{l}<\mathrm{MDL} \\
(6.72)\end{array}$ & $\begin{array}{l}<\mathrm{MDL} \\
(28.4)\end{array}$ \\
\hline & Max. & 9.87 & 24.7 & 612 & 41.8 & 801 & 174 & 31.8 & 30.9 & 129 & 1053.45 & 242.34 & 48.5 & 399 \\
\hline & Median & 7.82 & 19.8 & 12.7 & 15.5 & 123 & 56.1 & 27.7 & 19.1 & 47.5 & 219.54 & 117.54 & 20.7 & 69.9 \\
\hline & $\begin{array}{l}\text { GM } \\
\text { RURAL }\end{array}$ & 7.62 & 19.8 & 24.2 & 17.8 & 80.1 & 42.6 & 27.4 & 15.0 & 46.2 & 191.05 & 81.21 & 18.4 & 70.6 \\
\hline & $\mathrm{n}^{*}$ & & & 8 & 11 & 8 & 9 & 2 & 0 & 7 & 11 & 10 & 7 & 11 \\
\hline & Mean & 8.47 & 20.2 & 22.9 & 13.2 & 124 & 28.5 & 29.4 & $<\mathrm{MDL}$ & 82.2 & 201 & 64.3 & 20.3 & 103 \\
\hline & SD & 1.92 & 3.92 & 16.2 & 4.64 & 79.0 & 21.2 & 29.5 & $<\mathrm{MDL}$ & 75.7 & 167 & 34.1 & 9.41 & 219 \\
\hline & $\operatorname{Min} .(* *)$ & 5.77 & 10.6 & $\begin{array}{l}<\mathrm{MDL} \\
(6.76)\end{array}$ & $\begin{array}{l}<\mathrm{MDL} \\
(4.61)\end{array}$ & $\begin{array}{l}<\mathrm{MDL} \\
(25.2)\end{array}$ & $\begin{array}{l}<\text { MDL } \\
(4.53)\end{array}$ & $\begin{array}{l}<\mathrm{MDL} \\
(8.55)\end{array}$ & $<\mathrm{MDL}$ & $\begin{array}{l}<\mathrm{MDL} \\
(7.44)\end{array}$ & $\begin{array}{l}<\mathrm{MDL} \\
(15.9)\end{array}$ & $\begin{array}{l}<\mathrm{MDL} \\
(20.7)\end{array}$ & $\begin{array}{l}<\mathrm{MDL} \\
(5.39)\end{array}$ & $\begin{array}{l}<\text { MDL } \\
(7.50)\end{array}$ \\
\hline & Max. & 12.7 & 24.7 & 46.4 & 20.5 & 279 & 73.8 & 50.3 & $<\mathrm{MDL}$ & 174 & 514 & 111 & 34.2 & 758 \\
\hline & Median & 8.30 & 19.2 & 17.8 & 13.5 & 125 & 24.3 & 29.4 & $<\mathrm{MDL}$ & 36.3 & 150 & 68.3 & 20.3 & 35.6 \\
\hline & GM & 8.28 & 19.8 & 17.6 & 12.4 & 97.9 & 21.9 & 20.7 & $<\mathrm{MDL}$ & 47.4 & 128 & 54.4 & 17.8 & 39.7 \\
\hline \multicolumn{15}{|l|}{ URBAN } \\
\hline \multirow[t]{15}{*}{$2^{\mathrm{ND}}$ PERIOD } & $\mathrm{n}^{*}$ & & & 15 & 16 & 15 & 15 & 5 & 3 & 4 & 16 & 16 & 11 & 16 \\
\hline & Mean & 9.08 & 18.8 & 289 & 208 & 363 & 78.8 & 378 & 58.5 & 37.8 & 1070 & 117 & 25.7 & 162 \\
\hline & SD & 1.85 & 3.52 & 795 & 440 & 647 & 157 & 772 & 69.7 & 45.3 & 1892 & 87.9 & 20.9 & 212 \\
\hline & Min. $(* *)$ & 5.83 & 12.9 & $\begin{array}{l}<\mathrm{MDL} \\
(5.21)\end{array}$ & 18.6 & $\begin{array}{l}<\mathrm{MDL} \\
(32.2)\end{array}$ & $\begin{array}{l}<\mathrm{MDL} \\
(5.34)\end{array}$ & $\begin{array}{l}<\mathrm{MDL} \\
(13.6)\end{array}$ & $\begin{array}{l}<\mathrm{MDL} \\
(2.86)\end{array}$ & $\begin{array}{l}<\mathrm{MDL} \\
(7.15)\end{array}$ & 53.0 & 6.25 & $\begin{array}{l}<\mathrm{MDL} \\
(4.01)\end{array}$ & 36.2 \\
\hline & Max. & 11.9 & 25.6 & 3112 & 1375 & 2153 & 637 & 1758 & 137 & 104 & 6508 & 281 & 70.0 & 878 \\
\hline & Median & 9.49 & 17.7 & 39.3 & 35.4 & 125 & 29.2 & 28.6 & 36.1 & 19.9 & 255 & 106 & 17.0 & 70.5 \\
\hline & $\mathrm{GM}$ & 8.89 & 18.5 & 47.4 & 61.3 & 144 & 35.3 & 60.7 & 24.1 & 21.8 & 374 & 72.7 & 19.7 & 101 \\
\hline & RURAL & & & & & & & & & & & & & \\
\hline & $\mathrm{n}^{*}$ & & & 13 & 16 & 16 & 14 & 7 & 1 & 8 & 16 & 15 & 13 & 16 \\
\hline & Mean & 8.79 & 18.8 & 74.4 & 111 & 198 & 46.5 & 66.5 & 44.2 & 54.5 & 551 & 98.2 & 20.9 & 91.9 \\
\hline & $\mathrm{SD}$ & 1.54 & 3.52 & 130 & 307 & 397 & 74.8 & 142 & 0.00 & 121 & 1324 & 83.5 & 10.9 & 91.0 \\
\hline & $\operatorname{Min} .(* *)$ & 5.61 & 12.9 & $\begin{array}{l}<\mathrm{MDL} \\
(5.86)\end{array}$ & 19.1 & 18.2 & 12.3 & 7.22 & 44.2 & 6.35 & 76.8 & 11.5 & 5.55 & 19.5 \\
\hline & Max. & 12.2 & 25.6 & 482 & 1261 & 1666 & 303 & 389 & 44.2 & 354 & 5502 & 369 & 46.5 & 408 \\
\hline & Median & 9.04 & 17.7 & 11.6 & 31.4 & 96.6 & 25.3 & 14.0 & 44.2 & 11.0 & 218 & 85.5 & 19.0 & 72.7 \\
\hline & $\mathrm{GM}$ & 8.66 & 18.5 & 26.6 & 41.5 & 96.7 & 28.8 & 19.3 & 44.2 & 17.0 & 243 & 73.2 & 18.3 & 69.1 \\
\hline \multicolumn{15}{|l|}{ URBAN } \\
\hline \multirow[t]{15}{*}{$3^{\text {RD }}$ PERIOD } & $\mathrm{n}^{*}$ & & & 9 & 9 & 14 & 11 & 6 & 1 & 4 & 16 & 15 & 15 & 14 \\
\hline & Mean & 3.12 & 4.80 & 53.8 & 40.3 & 112 & 23.7 & 37.0 & 4.11 & 35.1 & 199 & 164 & 63.4 & 566 \\
\hline & SD & 0.88 & 4.34 & 99.9 & 20.2 & 156 & 25.2 & 36.0 & na & 19.6 & 281 & 234 & 63.9 & 225 \\
\hline & Min. $(* *)$ & 1.61 & -3.64 & $\begin{array}{l}<\mathrm{MDL} \\
(7.14)\end{array}$ & $\begin{array}{l}<\mathrm{MDL} \\
(10.0)\end{array}$ & $\begin{array}{l}<\mathrm{MDL} \\
(7.63)\end{array}$ & $\begin{array}{l}<\mathrm{MDL} \\
(3.86)\end{array}$ & $\begin{array}{l}<\mathrm{MDL} \\
(5.92)\end{array}$ & na & $\begin{array}{l}<\mathrm{MDL} \\
(14.1)\end{array}$ & 33.8 & 14.1 & 7.18 & 197 \\
\hline & Max. & 4.55 & 12.83 & 319 & 70.7 & 603 & 76.5 & 96.0 & na & 61.4 & 1174 & 969 & 269 & 1099 \\
\hline & Median & 3.22 & 3.31 & 24.3 & 47.5 & 48.8 & 10.2 & 22.1 & 4.11 & 32.5 & 87.8 & 98.7 & 50.5 & 562 \\
\hline & GM & 2.99 & 4.23 & 25.2 & 34.4 & 57.0 & 14.0 & 23.8 & 4.11 & 30.9 & 116 & 98.5 & 45.3 & 520 \\
\hline & RURAL & & & & & & & & & & & & & \\
\hline & $\mathrm{n}^{*}$ & & & 11 & 13 & 13 & 11 & 12 & 0 & 3 & 15 & 15 & 15 & 14 \\
\hline & Mean & 3.85 & 4.80 & 41.2 & 63.9 & 133 & 13.9 & 23.9 & $<\mathrm{MDL}$ & 16.8 & 307 & 187 & 85.2 & 709 \\
\hline & SD & 1.86 & 4.34 & 43.0 & 35.1 & 182 & 13.3 & 24.0 & $<\mathrm{MDL}$ & 13.2 & 309 & 197 & 103 & 559 \\
\hline & $\operatorname{Min} .(* *)$ & 1.18 & -3.64 & $\begin{array}{l}<\mathrm{MDL} \\
(6.54)\end{array}$ & $\begin{array}{l}<\mathrm{MDL} \\
(17.4)\end{array}$ & $\begin{array}{l}<\mathrm{MDL} \\
(10.7)\end{array}$ & $\begin{array}{l}<\mathrm{MDL} \\
(4.61)\end{array}$ & $\begin{array}{l}<\mathrm{MDL} \\
(6.17)\end{array}$ & $<\mathrm{MDL}$ & $\begin{array}{l}<\mathrm{MDL} \\
(7.03)\end{array}$ & 28.3 & 31.9 & 16.3 & 278 \\
\hline & Max. & 7.91 & 12.83 & 150 & 120 & 695 & 50.4 & 93.4 & $<\mathrm{MDL}$ & 31.8 & 1114 & 747 & 383 & 2422 \\
\hline & Median & 3.80 & 3.31 & 21.4 & 63.0 & 69.9 & 8.24 & 18.5 & $<\mathrm{MDL}$ & 11.7 & 196 & 107 & 45.5 & 496 \\
\hline & GM & 3.43 & 4.23 & 25.9 & 54.1 & 73.6 & 10.5 & 17.5 & $<\mathrm{MDL}$ & 13.8 & 213 & 128 & 55.2 & 585 \\
\hline \multicolumn{15}{|l|}{ URBAN } \\
\hline \multirow[t]{12}{*}{$4^{\mathrm{TH}}$ PERIOD } & $\mathrm{n}^{*}$ & & & 14 & 8 & 14 & 14 & 5 & 1 & 6 & 16 & 14 & 14 & 3 \\
\hline & Mean & 4.39 & 9.68 & 25.8 & 18.9 & 139 & 15.8 & 16.8 & 2.11 & 22.3 & 193 & 100 & 43.4 & 5.29 \\
\hline & SD & 0.81 & 3.63 & 22.1 & 7.74 & 138 & 16.3 & 9.33 & na & 17.7 & 148 & 28.9 & 9.63 & 1.71 \\
\hline & $\operatorname{Min} .(* *)$ & 3.01 & 3.51 & $\begin{array}{l}<\mathrm{MDL} \\
(5.81)\end{array}$ & $\begin{array}{l}<\mathrm{MDL} \\
(12.6)\end{array}$ & $\begin{array}{l}<\mathrm{MDL} \\
(30.4)\end{array}$ & $\begin{array}{l}<\text { MDL } \\
(5.48)\end{array}$ & $\begin{array}{l}<\mathrm{MDL} \\
(8.27)\end{array}$ & 2.11 & $\begin{array}{l}<\mathrm{MDL} \\
(6.17)\end{array}$ & 40.6 & $\begin{array}{l}<\mathrm{MDL} \\
(60.5)\end{array}$ & $\begin{array}{l}<\mathrm{MDL} \\
(30.6)\end{array}$ & $\begin{array}{l}<\mathrm{MDL} \\
(3.41)\end{array}$ \\
\hline & Max. & 6.13 & 15.60 & 76.5 & 36.7 & 515 & 65.2 & 27.2 & 2.11 & 56.3 & 565 & 145 & 65.7 & 6.76 \\
\hline & Median & 4.26 & 8.89 & 18.1 & 17.0 & 79.5 & 9.32 & 13.8 & 2.11 & 18.8 & 139 & 93.8 & 41.7 & 5.69 \\
\hline & GM & 4.32 & 9.01 & 18.9 & 17.9 & 93.9 & 11.9 & 14.7 & 2.11 & 17.8 & 148 & 96.2 & 42.4 & 5.08 \\
\hline & RURAL & & & & & & & & & & & & & \\
\hline & $\mathrm{n}^{*}$ & & & 15 & 8 & 15 & 16 & 2 & 2 & 2 & 16 & 15 & 15 & 3 \\
\hline & Mean & 5.45 & 9.68 & 40.3 & 18.3 & 56.1 & 10.2 & 11.3 & 4.69 & 7.35 & 123 & 93.1 & 38.1 & 19.7 \\
\hline & $\mathrm{SD}$ & 1.82 & 3.63 & 71.9 & 5.98 & 40.8 & 8.10 & 0.20 & 1.53 & 2.00 & 92.6 & 76.9 & 17.7 & 15.3 \\
\hline & Min. $(* *)$ & 2.64 & 3.51 & $\begin{array}{l}<\mathrm{MDL} \\
(4.73)\end{array}$ & $\begin{array}{l}<\mathrm{MDL} \\
(8.89)\end{array}$ & $\begin{array}{l}<\mathrm{MDL} \\
(10.3)\end{array}$ & 4.04 & $\begin{array}{l}<\mathrm{MDL} \\
(11.2)\end{array}$ & $\begin{array}{l}<\mathrm{MDL} \\
(3.61)\end{array}$ & $\begin{array}{l}<\mathrm{MDL} \\
(5.94)\end{array}$ & 12.2 & $\begin{array}{l}<\mathrm{MDL} \\
(38.7)\end{array}$ & $\begin{array}{l}<\mathrm{MDL} \\
(19.8)\end{array}$ & $\begin{array}{l}<\mathrm{MDL} \\
(2.95)\end{array}$ \\
\hline
\end{tabular}




\begin{tabular}{|c|c|c|c|c|c|c|c|c|c|c|c|c|c|}
\hline & $\begin{array}{l}\mathrm{R} \\
\left(\mathrm{m}^{3} /\right. \\
\text { day) }\end{array}$ & $\mathrm{T}\left({ }^{\circ} \mathrm{C}\right)$ & $\Sigma \mathrm{HCHs}$ & HCB & $\Sigma$ DDTs & $\Sigma$ ENDO & $\Sigma$ HEP & $\mathrm{TC}+\mathrm{CC}$ & $\Sigma$ ENDs & $\Sigma_{22} \mathrm{OCPs}$ & $\Sigma_{43} \mathrm{PCBs}$ & $\Sigma_{7} \mathrm{iPCB}$ & $\Sigma_{14} \mathrm{PBDEs}$ \\
\hline Max. & 8.69 & 15.60 & 298 & 29.3 & 135 & 38.9 & 11.4 & 5.78 & 8.77 & 369 & 338 & 87.6 & 32.8 \\
\hline Median & 5.73 & 8.89 & 21.5 & 18.1 & 44.2 & 7.99 & 11.3 & 4.69 & 7.35 & 94.9 & 71.4 & 36.6 & 23.4 \\
\hline GM & 5.14 & 9.01 & 23.3 & 17.4 & 42.0 & 8.70 & 11.3 & 4.57 & 7.22 & 94.6 & 76.5 & 35.2 & 13.1 \\
\hline
\end{tabular}

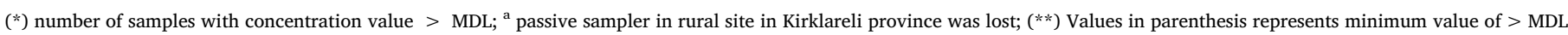

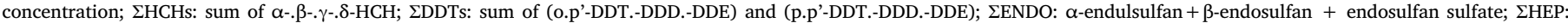

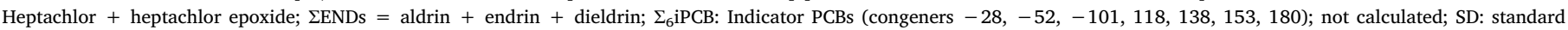
deviation; Min. Minimum value; Max. Maximum value; GM: Geometric mean.

seasonality was evaluated for two temperature regimes: samples collected at higher (range: $14.4-25.6{ }^{\circ} \mathrm{C}$ ) and lower (range: $-3.6-14.1{ }^{\circ} \mathrm{C}$ ) than average $\left(14.2^{\circ} \mathrm{C}\right)$ temperatures over the one-year sampling period. Comparison of the groups would indicate temperature dependence in relation to seasonal variation. It is found that most of the target chemicals were at higher average levels in the Period II (August-October 2014), except Mirex, $\Sigma_{43}$ PCBs, and $\Sigma_{14}$ PBDEs, which were at higher concentrations in Period III (November 2014-January 2015). Therefore, it may be speculated that the warmer the sampling period, the higher the average pollutant concentration probably due to volatilization from sinks or contaminated sites. Zhang et al. (2013) also reported the highest average concentration of six indicator PCBs in winter as $44.4 \mathrm{pg} / \mathrm{m}^{3}$ compared to summer $\left(21.6 \mathrm{pg} / \mathrm{m}^{3}\right.$ ), while Baek et al. (2010) measured higher mean concentration of $\Sigma_{8} \mathrm{PCBs}$ in spring-summer period $\left(77.7 \mathrm{pg} / \mathrm{m}^{3}\right)$ compared to fall-winter period $\left(31.7 \mathrm{pg} / \mathrm{m}^{3}\right)$. Vilavert et al. (2014) also reported higher average $\Sigma_{7}$ PCB (indicators) levels with $27.7 \mathrm{pg} / \mathrm{m}^{3}$ in spring in Spain. $\Sigma$ HCHs, TC + CC, $\Sigma$ DDT, and $\Sigma$ DDE levels were higher in autumn $\left(38.5 \mathrm{pg} / \mathrm{m}^{3}, 331 \mathrm{pg} / \mathrm{m}^{3}, 215 \mathrm{pg} /\right.$ $\mathrm{m}^{3}, 178 \mathrm{pg} / \mathrm{m}^{3}$, respectively) in China (Zhang et al., 2013).

The difference in the median concentrations of the two temperature groups were significant at urban sites for HCB $(p<.0001), p, p^{\prime}$-DDT $(p=.039)$, dieldrin $(p=.023)$, and $\beta$-endosulfan $(p=.001)$. Endo-SO $\mathrm{S}_{4}$ was not found at urban sites, and the median levels of the remaining OCPs, $\Sigma_{43}$ PCBs and $\Sigma_{14}$ PBDEs were not significantly different at urban sites. The difference in the median levels with temperature was significant at rural sites for HCB $(p<.0001)$, dieldrin $(p=.002)$, endrin $(p=.007)$, heptachlor $(p=.002), \quad p, p^{\prime}$-DDE $(p=.010)$, Mirex $(p=.044), \beta$-endosulfan $(p=.012)$, and $\Sigma_{43} \mathrm{PCBs}(p=.047)$, while the median concentrations of the other OCPs and $\Sigma_{14} \mathrm{PBDEs}$ were not significantly different at rural sites. In general, HCB, DDTs, and endosulfan had higher concentrations in the warmer periods both at urban and rural sites, which points out the significance of the secondary emissions. PCBs also had similar behavior at urban sites depending on the significance level ( $p=$.047).

\subsection{Factor analysis}

Scree and loading plots (Figs. S10-S15), and final statistics and factor loadings (Tables S6-S17) of the analyses presented in this section can be found in the Supplementary Material. The analysis of OCPs resulted in 6 factors for both urban and rural sites, explaining $79 \%$ and $81 \%$ of the variation, respectively. For rural sites, Factor- 1 contributed with $41 \%$, with high loadings of $\beta$-endosulfan, Endo- $\mathrm{SO}_{4}$, chlordane (TC and (C), heptachlor epoxide, dieldrin, endrin, $\alpha-\mathrm{HCH}$, and $p, p^{\prime}$-DDE, which contain both some parent and some degradation products. Factor-2, contributing with $14 \%$, is loaded by HCH isomers $(\beta-, \gamma-$, and $\delta$-) and aldrin. The remaining factors are comprised of $p, p^{\prime}$-DDT and heptachlor (Factor-3), $o, p^{\prime}$-DDT and $o, p^{\prime}$-DDE (Factor-4), Mirex (Factor5), and HCB (Factor-6). Similar to rural sites, Factor-1, -2 and -3 (explaining $33 \%, 16 \%$, and $14 \%$ of the variation, respectively) are a mix of chlordane (CC and TC), endosulfan ( $\alpha$-, $\beta$-, and - $\mathrm{SO}_{4}$ ), $p, p^{\prime}$ - and $o, p^{\prime}$-DDT, $p, p^{\prime}$-DDE, $\mathrm{HCH}$ isomers $(\alpha-, \beta-, \gamma$-, and $\delta$-), and dieldrin and endrin for urban sites containing both some parent and degradation compounds. The remaining factors are mainly formed of parent compounds: $\beta$-endosulfan and heptachlor (Factor-4), aldrin, Mirex (Factor-5), and p,p'DDT (Factor-6). In summary, the measured OCP concentrations were mainly contributed both by primary sources of $\mathrm{HCHs}$ and chlordane and by secondary sources with degradation products such as Endo- $\mathrm{SO}_{4}$ and heptachlor epoxide, whereas DDT, HCB, and Mirex contribute much less.

The analysis of PCBs resulted in 9 and 7 factors for rural and urban sites, explaining $85 \%$ and $83 \%$ of the variation, respectively. However, Factor- 1 explained $>40 \%$, and three more contributed with $>5 \%$ for both rural and urban sites. For rural sites, Factor-1 accounting for a variation of $43 \%$, is highly loaded by PCBs $-180,-141,-167,-87$, $-151,-153,-132,-149,-158$, and -110 . Factor- 2 is highly loaded by PCBs -194 and -157 while Factor- 3 is moderately loaded by -95 and -203 , explain $8.7 \%$ and $7.4 \%$ of the variation, respectively. These factors, with a total variation of $59 \%$ explained, contain congeners of Aroclors 1254 and 1260, therefore, can be ascribed to technical PCB mixtures (Aydin et al., 2014; Cetin, 2016; Odabasi et al., 2016; and references therein). Factor-4 (PCB-123 and -118) and Factor5 (PCB-52, -170, -114) may be ascribed to combustion (Aydin et al., 2014), Factor-6 (PCB-31, -28, and -18) and Factor-9 (PCB-22) may be indicating LRAT (Gregoris et al., 2014; Stafilov et al., 2011; and references therein), while Factor-6 (PCB-187 and -183) can also be considered as technical mixtures (Kanechlor-600, Aydin et al., 2014; Cetin, 2016; Odabasi et al., 2016; and references therein). Differently for urban sites, Factor-1 accounting for $44 \%$ of the variation, is highly loaded by PCBs $-110,-18,153,-31,-138,-28$, and moderately loaded by $16 \mathrm{CBs}$, which contain tri-, penta-, and hexa-CBs, indicating short and long range atmospheric transport (Stafilov et al., 2011; references therein; Gregoris et al., 2014). Factor-2 has high loadings of PCBs $-189,-104,-174,-194$, and -157 , explains $14 \%$ of the variation with highly chlorinated congeners and can be ascribed to Araclor 1260. Factor-3, explaining $8.7 \%$ and loaded by PCBs -141 , -203 , and -99 can also be ascribed to short range atmospheric transport (Stafilov et al., 2011; references therein; Gregoris et al., 2014). Factor-4, explaining $6.3 \%$ and loaded by PCBs -118 and -123 , could indicate combustion, however, the moderate negative loading by PCB-170 does not allow for this interpretation. In summary, the urban concentrations were contributed mainly by the technical mixtures and their constituents' transport from short and long distances.

The analysis was also conducted with the overall dataset that was formed by adding PBDEs to OCPs and PCBs. The analysis of the ruralsites dataset revealed 17 factors. However, only four factors contributed with $>5 \%$, explaining a total of $52 \%$ of the variation. Factor- 1 , explaining $24.8 \%$, has high loadings of PCB congeners $(-87,-180$, $-141,-151,-167,-153,-149,-132,-158,-110)$ and PBDE-85. Factor-2, explaining $13.3 \%$, is highly loaded by OCPSs: $\alpha$-HCH, chlordane (CC and TC), $\beta$-endosulfan, dieldrin and endrin, and degradation products including Endo- $\mathrm{SO}_{4}$, heptachlor epoxide, and $p, p^{\prime}$-DDE. Factors -3 and -5 , explaining $7.9 \%$ and $4.6 \%$, respectively, have high loadings of PBDEs $(-47,-99,-190$ and $-138,-28$, respectively), 
while Factor-4, explaining 6\%, of PCBs ( -194 , and -157$)$ and Factor6 , explaining $4.4 \%$, of aldrin, along with moderate loadings of $(\delta-, \beta-, \gamma-$ $\mathrm{HCHs})$. In addition, although with small percentages of variation explained, other parent OCPs (HCB, $\alpha$-endosulfan, Mirex, $p$, $p^{\prime}$-DDT as Factors $-17,-16,-15,-10$, respectively) and DDTs (o,p'-DDE and $o, p^{\prime}$-DDT as Factors -12 and -13 , respectively) also appear as sources. In addition to $p, p^{\prime}$-DDT, Factor-10 includes PCB-31, -28 , and -18 , indicating that $p, p^{\prime}$-DDT is associated with LRAT. The analysis of the urban-sites dataset revealed 16 factors. However, only four factors contributed with $>5 \%$, explaining a total of $57 \%$ of the variation. Factor-1, explaining 27.1\%, has high loadings of PCBs $(-31,-105$, $-167,-151,-110,-18$, and -28 ). OCPs (heptachlor epoxide, CC, $\gamma$-HCH, $\beta$-HCH, TC, $\alpha-\mathrm{HCH})$ and PBDEs $(-85,-154$, and -66$)$ are high loadings to Factor-2, explaining $14.3 \%$. PCBs $(-174,-189$, $-104,-194$, and -189$)$ are high loadings to Factor-3, explaining 8.4\%. PBDEs ( $-47,-190$, and -99$)$ and PCBs $(-118$ and -123$)$ load Factor- 4 with $7.0 \%$ variation explained. Factors -5 and -6 , with respective contributions of $4.9 \%$ and $4.7 \%$ to the explained variation, are loaded by $p, p$ '-DDD, endosulfans ( $\beta$ - and $-\mathrm{SO}_{4}$ ), and PCBs $-203,-141$, -99 , respectively. In addition, endrin-dieldrin (Factor-7), o, $p$ 'DDT (Factor-10), aldrin and Mirex (Factor-14), PBDE-209 (Factor-11) appear as separate sources. Identification of PCBs, OCPs, and PBDEs having separate variations at rural sites (Factors -1 to -5 , explaining $56 \%$ of the variation) and appearance of parent OCPs as separate sources (HCB, $\alpha$-endosulfan, Mirex, $p, p^{\prime}$-DDT) along with attributions made within PCBs and OCPs datasets indicate local sources/short range transport and LRAT contribute to the measured concentrations. A similar elucidation can also be made for urban sites except that some OCPs and PBDEs appear to show similar variation (Factor-2) indicating a common urban source, which may be co-contaminated soils, OCP-applied buildings and/or building materials (Melymuk et al., 2013).

\section{Conclusions}

The aims of this study were to measure ambient air concentrations of 43 PCBs, 22 OCPs, and 14 PBDEs in urban and rural sites of 16 cities by PUF-PAS, to examine spatial and seasonal variations on an east to west and south to north transect, and to generate the first large-scale nationwide data set for atmospheric POPs in Turkey. Results of the study have built up a valuable data focused on a geographical area poorly described until now. A broad range of air concentrations were observed for compounds of interest in addition to a fairly consistent pattern of relative abundance for each group of contaminants across seasons and locations. Levels determined in this study were in consonance with levels of target chemicals reported in other studies conducted in Turkey and with levels found for European sites, with some exceptions. Penta-CBs had the highest portion in the total concentration with 54.3\%; the contribution decreased as the molecular weight of homologue groups increased. The five OCPs with highest levels were listed as $p$, $p$-DDE, HCB, $\alpha$-HCH, $\beta$-HCH, and $p, p$ '-DDT. One-year overall mean concentration of $\Sigma_{14} \mathrm{PBDEs}$ for urban and rural sites were $183 \pm 260 \mathrm{pg} / \mathrm{m}^{3}$ and $200 \pm 387 \mathrm{pg} / \mathrm{m}^{3}$, respectively. The difference in concentrations of urban and rural sites was not significant, whereas some compounds were at significantly higher levels in the warmer periods indicating the secondary emissions, which was also pointed to LRAT from secondary emission areas by the factor analysis for the whole dataset.

Usage of chemicals of interest of this study has been forbidden in Turkey in different times in a time span from 1979 to 2001. Therefore, the reason for detection of varying levels which can be considered as higher concentrations in some cases in comparison to the values reported in literature around the world may be due to local volatilization from secondary sources and/or waste sites as well as LRAT from surrounding areas. Particularly, levels and presences of target chemicals in Kars, Van and Kirklareli provinces that lack any known sources of PCBs and OCPs may be an important indicator of LRAT of these chemicals. A clear conclusion of the current study is the lack of unequivocal temporal and spatial trends of target POPs in Turkish ambient air. This, in turn, makes it impossible to carry out an assessment, in any degree, of effectiveness of any measurements implemented by the Stockholm Convention in the country. Therefore, formation, implementation and maintenance of a long-term and regular Turkish air monitoring program in a more wider spatial coverage and in much longer time periods is a must for the exact assessment of POPs time trends, distribution and fate in the environment.

\section{Acknowledgements}

This work was supported by Turkish Scientific and Technological Resarch Council (TUBITAK) for the financial support (Grant \# 112Y314). Dr. Henry Alegria was financially supported by TUBITAK as a visiting scientist (Grant \#21514107-221.01-8290). We thank all volunteers who helped us to deploy the samplers and more importantly for taking care of the samplers during the course of the study.

\section{Appendix A. Supplementary data}

Supplementary data related to this article can be found at http://dx. doi.org/10.1016/j.atmosenv.2018.01.021.

\section{References}

Acara, A., 2006. Turke Y's Draft National Im Plementation Plan for the Stockholm Convention on Persistent Organic Pollutants. UNIDO-POPs Project No. GF/TUR/03/ 008. Ministry of Environment and Forestry, Ankara (in Turkish).

Acara, A., 2008. Turkey's National Implementation Plan for the Stock Holm Convention on Persi Stent Organic Pollutants. UNIDO-POPs Project No. GF/TUR/03/008. Ministry of Environment and Forestry, Ankara (in Turkish).

Ahioğlu, S.S., 2008. Health and Safety and Risk Assessment in Agricultural Sector Ministry of Labour and Social Security, General Directorate of Occupational Health and Safety, Occupational Health and Center, Specialized Thesis on Occupational Health and Safety, Ankara, Turkey (in Turkish Language).

Aliyeva, G., Kurkova, R., Hovorkova, I., Klánová, J., Halsall, C., 2012. Organochlorine pesticides and polychlorinated biphenyls in air and soil across Azerbaijan. Environ. Sci. Pollut. Res. 19, 1953-1962.

Atlas, E., Giam, C.S., 1988. Ambient concentration and precipitation scavenging of atmospheric organic pollutants. Water Air Soil Pollut. 38, 19-36.

ATSDR, 1995. Toxicological Profile for Mirex and Chlordecone. U.S.Department of Health and Human Services, Public Health Service Agency for Toxic Substances and Disease Registry available at: https://www.atsdr.cdc.gov/toxprofiles/tp66.pdf, Accessed date: 20 June 2017.

ATSDR, 2000. Toxicological Profile for Polychlorinated Biphenyls (PCBs). U.S. Department of health and human services, Public Health Service, Agency for Toxic Substances and Disease Registry Final Report. https://www.atsdr.cdc.gov/ ToxProfiles/tp17.pdf, Accessed date: 21 May 2017.

ATSDR, 2002. Toxicological Profile for DDT, DDE, and DDD. U.S.Department of Health and Human Services, Public Health Service Agency for Toxic Substances and Disease Registry available at: https://www.atsdr.cdc.gov/toxprofiles/tp35.pdf, Accessed date: 25 June 2017.

Aydin, Y.M., Kara, M., Dumanoglu, Y., Odabasi, M., Elbir, T., 2014. Source apportionment of polycyclic aromatic hydrocarbons (PAHs) and polychlorinated biphenyls (PCBs) in ambient air of an industrial region in Turkey. Atmos. Environ. 97, 271-285.

Baek, S.-Y., Sung-Deuk, C., Se-Jin, L., Yoon-Seok, C., 2008. Assessment of the spatial distribution of coplanar PCBs, PCNs, and PBDEs in a multi-industry region of South Korea using passive air samplers. Environ. Sci. Technol. 42 (19), 7336-7340.

Baek, S.-Y., Sung-Deuk, C., Hyokeun, P., Jung-Ho, K., Yoon-Seok, C., 2010. Spatial and seasonal distribution of polychlorinated biphenyls (PCBs) in the vicinity of an iron and steel making plant. Environ. Sci. Technol. 44 (8), 3035-3040.

Birgul, A., Tasdemir, Y., 2012. Determination of the sampler type and rainfall effect on the deposition fluxes of the polychlorinated biphenyls. Sci. World J. 1-10 Article ID 798020.

Birgul, A., Kurt-Karakus, P., Alegria, H., Gungormus, E., Celik, H., Cicek, T., Guven, E., 2017. Polyurethane foam (PUF) disk passive samplers derived polychlorinated biphenyls (PCBs) concentrations in the ambient air of Bursa-Turkey: spatial and temporal variations and health risk assessment. Chemosphere 168, 1345-1355.

Bowes, G.W., Jonkel, C.J., 1975. Presence and distribution of polychlorinated biphenyls (PCB) in arctic and subarctic marine food chains. J. Fish. Board Can. 32, 2111-2123.

Bozlaker, A., Odabasi, M., Muezzinoglu, A., 2008. Dry deposition and soil-air gas exchange of polychlorinated biphenyls (PCBs) in an industrial area. Environ. Pollut. 156 (3), 784-793.

Brubaker, W.W., Hites, R.A., 1998. OH reaction kinetics of gas-phase $\alpha$ - and $\gamma$ - hexachlorocyclohexane and hexachlorobenzene. Environ. Sci. Technol. 32 (6), 766-769.

Bussian, B.M., Pandelova, M., Lehnik-Habrink, P., Aichner, B., Henkelmann, B., Schramm, K.W., 2015. Persistent endosulfan sulfate is found with highest abundance among 
endosulfan I, II, and sulfate in German forest soils. Environ. Pollut. 206, 661-666. Carrera, G., Fern andez, P., Grimalt, J.O., Ventura, M., Camarero, L., Catalan, J., Nickus, U., Thies, H., Psenner, R., 2002. Atmospheric deposition of organochlorine compounds to remote high mountain Lakes of Europe. Environ. Sci. Technol. 36, 2581-2588.

Cetin, B., Odabasi, M., 2007. Particle-phase dry deposition and air-soil gas exchange of polybrominated diphenyl ethers (PBDEs) in Izmir, Turkey. Environ. Sci. Technol. 41, 4986-4992.

Cetin, B., Odabasi, M., 2008. Atmospheric concentrations and phase partitioning of polybrominated diphenyl ethers (PBDEs) in Izmir, Turkey. Chemosphere 71 1067-1078.

Cetin, B., 2016. Investigation of PAHs, PCBs and PCNs in soil around heavily industrialized area in Kocaeli, Turkey: concentrations, distributions, sources and potential health risks. Sci. Total Environ. 560-561, 160-169.

Cetin, B., Yurdakul, S., Keleş, M., Çelik, I., Öztürk, F., Doğan, C., 2017a. Atmospheric concentrations, distributions and air-soil exchange tendencies of PAHs and PCBs in a heavily industrialized area in Kocaeli, Turkey. Chemosphere 183, 69-79.

Cetin, B., Öztürk, F., Keleş, M., Yurdakul, S., 2017b. PAHs and PCBs in an eastern Mediterranean Megacity, Istanbul: their spatial and temporal distributions, air-soil exchange and toxicological effects. Environ. Pollut. 220, 1322-1332.

Cindoruk, S.S., 2011. Atmospheric organochlorine pesticide (OCP) levels in a metropolitan city in Turkey. Chemosphere 82, 78-87.

Cindoruk, S.S., Esen, F., Tasdemir, Y., 2007. Concentration and gas/part,cle partitioning of polychlorinated biphenyls (PCBs) at an industrial site at Bursa, Turkey. Atmos. Res. 85, 338-350.

Cindoruk, S.S., Tasdemir, Y., 2014. The investigation of atmospheric deposition distribution of organochlorine pesticides (OCPs) in Turkey. Atmos. Environ. 87, 207-217.

Cleverly, D., Ferrario, J., Byrne, C., Riggs, K., Joseph, D., Hartford, P., 2007. A general indication of the contemporary background levels of PCDDs, PCDFs, 71 and coplanar PCBs in the ambient air over rural and remote areas of the United States. Environ. Sci. Technol. 41 (5), 1537-1544.

Devi, N.L., Qi, S., Chakraborty, P., Zhang, G., Yadav, I.C., 2011. Passive air sampling of organochlorine pesticides in a northeastern state of India, Manipur. J. Environ. Sci. 23, 808-815.

Du, S., Wall, S.J., Cacia, D., Rodenburg, L.A., 2009. Passive air sampling for polychlorinated biphenyls in the Philadelphia metropolitan area. Environ. Sci. Technol. 43 (5), 1287-1292.

Dumanoglu, Y., Gaga, E., Gungormus, E., Sofuoglu, S.C., Odabasi, M., 2017. Spatial and seasonal variations, sources, air-soil exchange, and carcinogenic risk assessment for PAHs and PCBs in air and soil of Kutahya, Turkey, the province of thermal power plants. Sci. Total Environ. 580, 920-935.

Erickson, M.D., Kaley, R.G., 2011. Applications of polychlorinated biphenyls. Environ. Sci. Pollut. Res. 18, 135-151.

Érseková, A., Hilscherová, K., Klánová, J., Giesy, J.P., Novák, J., 2014. Effect based assessment of passive air samples from four countries in Eastern Europe. Environ. Monit. Assess. 186, 1-12.

Esen, F., 2013. Development of a passive sampling device using polyurethane foam (PUF) to measure polychlorinated biphenyls (PCBs) and organochlorine pesticides (OCPs) near landfills. Environ. Forensics 14 3905-39016.

Estellano, V.H., Pozo, K., Harner, T., Corsolini, S., Focardi, S., 2012. Using PUF disk passive samplers to simultaneously measure air concentrations of persistent organic pollutants (POPs) across the Tuscany Region, Italy. Atmos. Pollut. Res. 3, 88-94.

Gedik, K., Imamoglu, I., 2010. An assessment of the spatial distribution of polychlorinated biphenyl contamination in Turkey. Clean. - Soil, Air, Water 38 (2), 117-128.

Gouin, T., Harner, T., Blanchard, P., Mackay, D., 2005. Passive and active air samplers as complementary methods for investigating persistent organic pollutants in the Great Lakes basin. Environ. Sci. Technol. 39 (23), 9115-9122.

Gregoris, E., Argiriadis, E., Vecchiato, M., Zambon, S., De Pieri, S., Donateo, A., Contini, D., Piazza, R., Barbante, C., Gambaro, A., 2014. Gas-particle distribution, sources and health effects of polycyclic aromatic hydrocarbons (PAHs), polychlorinated biphenyls (PCBs) and polychlorinated naphthalenes (PCNs) in Venice aerosols. Sci. Total Environ. 476-477, 393-405.

Harner, T., 2016. v1 3 Template for Calculating PUF and SIP Disk Sample Air Volumes. March 11.

He, J., Balasubramanian, R., 2010. A comparative evaluation of passive and active samplers for measurements of gaseous semi-volatile organic compounds in the tropical atmosphere. Atmos. Environ. 44, 884-891.

Jaward, F.M., Farrar, N.J., Harner, T., Sweetman, A.J., Jones, K.C., 2004. Passive air sampling of PCBs, PBDEs, and organochlorine pesticides across Europe. Environ. Sci. Technol. 38, 34-41.

Kaya, E., Dumanoglu, Y., Kara, M., Altiok, H., Bayram, A., Elbir, T., Odabasi, M., 2012 Spatial and temporal variation and air-soil exchange of atmospheric PAHs and PCBs in an industrial region. Atmos. Pollut. Res. 3, 435-449.

Klánová, J., Kohoutek, J., Hamplová, L., Urbanová, P., Holoubek, I., 2006. Passive air sampler as a tool for long-term air pollution monitoring: Part 1. Performance assessment for seasonal and spatial variations. Environ. Pollut. 144, 393-405.

Klánová, J., Èupr, P., Kohoutek, J., Harner, T., 2008. Assessing the influence of meteorological parameters on the performance of polyurethane foam-based passive air samplers. Environ. Sci. Technol. 42, 550-555.

Kurt-Karakus, P.B., Alegria, H., Jantunen, L., Birgul, A., Topcu, A., Jones, K.C., Turgut, C., 2017. Polybrominated diphenyl ethers (PBDEs) and alternative flame retardants (NFRs) in indoor and outdoor air and indoor dust from Istanbul-Turkey: levels and an assessment of human exposure. Atmos. Pollut. Res. 8 (5), 801-815.

Kuzu, S.L., 2016. Compositional variation of PCBs, PAHs, and OCPs at gas phase and size segregated particle phase during dust incursion from the Saharan Desert in the northwestern Anatolian Peninsula. Adv. Meteorol. 2016, 7153286. http://dx.doi.org/ 10.1155/2016/7153286. 12 pages.

Kuzu, S.L., Saral, A., Summak, G., Coltu, H., Demir, S., 2014. Ambient polychlorinated biphenyl levels and their evaluation in a metropolitan city. Sci. Total Environ. 472, 13-19.

Kuzu, S.L., Saral, A., Gunes, G., Karadeniz, A., 2016. Evaluation of background soil and air polychlorinated biphenyl (PCB) concentrations on a hill at the outskirts of a metropolitan city. Chemosphere 154, 79-89.

Kuzu, S.L., Saral, A., 2017. Air and soil concentrations and source identification of ambient polychlorinated biphenyls in the northeastern Mediterranean region. Clean. Soil, Air, Water 45 (5), 1600050.

Lammel, G., Audy, O., Besis, A., Efstathiou, C., Eleftheriadis, K., Kohoutek, J., Kukučka, P., Mulder, M.D., Přibylová, P., Prokeš, R., Rusina, T.P., Samara, C., Sofuoglu, A., Sofuoglu, S.C., Taşdemir, Y., Vassilatou, V., Voutsa, D., Vrana, B., 2015. Air and seawater pollution and air-sea gas exchange of persistent toxic substances in the Aegean Sea: spatial trends of PAHs, PCBs, OCPs and PBDEs. Environ. Sci. Pollut. Res. 22, 11301-11313.

Li, Q.Q., Loganath, A., Chong, Y.S., Tan, J., Obbard, J.P., 2006. Persistent organic pollutants and adverse health effects in humans. J. Toxicol. Environ. Health, Part A 69, 1987-2005.

Marek, R.F., Thorne, P.S., Herkert, N.J., Awad, A.M., Hornbuckle, K.C., 2017. Airborne PCBs and OH-PCBs inside and outside urban and rural US schools. Environ. Sci. Technol. 51 (14), 7853-7860.

Meire, R.O., Lee, S.C., Targino, A.C., Torres, J.P.M., Harner, T., 2012. Air concentrations and transport of persistent organic pollutants (POPs) in mountains of southeast and southern Brazil. Atmos Pollut. Res. 3, 417-425.

Melymuk, L., Robson, M., Helm, P.A., Diamond, M.L., 2013. Application of land use regression to identify sources and assess spatial variation in urban SVOC concentrations. Environ. Sci. Technol. 47, 1887-1895.

Ockenden, W., Lohmann, R., Shears, J.R., Jones, K.C., 2001. The significance of PCBs in the atmosphere of the southern hemisphere. Environ. Sci. Pollut. Res. 8, 189-194.

Odabasi, M., Cetin, B., Demircioglu, E., Sofuoglu, A., 2008. Air-water exchange of polychlorinated biphenyls (PCBs) and organochlorine pesticides (OCPs) at a coastal site in Izmir Bay, Turkey. Mar. Chem. 109 (1), 115-129.

Odabasi, M., Bayram, A., Elbir, T., Seyfioglu, R., Dumanoglu, Y., Bozlaker, A., Demircioglu, H., Altiok, H., Yatkin, S., Cetin, B.N., 2009. Electric Arc furnaces for steel-making: hot spots for persistent organic pollutants. Environ. Sci. Technol. 43, 5205-5211.

Odabasi, M., Cetin, B., 2012. Determination of octanol-air partition coefficients of organochlorine pesticides (OCPs) as a function of temperature: application to air-soil exchange. J. Environ. Manag. 113, 432-439.

Odabasi, M., Falay, E.O., Tuna, G., Altiok, H., Kara, M., Dumanoglu, Y., Bayram, A., Tolunay, D., Elbir, T., 2015. Biomonitoring the spatial and historical variations of persistent organic pollutants (POPs) in an industrial region. Environ. Sci. Technol. 49, 2105-2114.

Odabasi, M., Dumanoglu, Y., Falay, E.O., Tuna, G., Altiok, H., Kara, M., Bayram, A., Tolunay, D., Elbir, T., 2016. Investigation of spatial distributions and sources of persistent organic pollutants (POPs) in a heavily polluted industrial region using tree components. Chemosphere 160, 114-125.

Odabasi, M., Dumanoglu, Y., Kara, M., Altiok, H., Elbir, T., Bayram, A., 2017. Spatial variation of PAHs and PCBs in coastal air, seawater, and sediments in a heavily industrialized region. Environ. Sci. Pollut. Res. 24, 13749-13759.

Official Gazette, 1993. Directive on Control of Hazardous Chemicals and Products. Official Gazette No: 21634, 11 July 1993.

Official Gazette, 2009a. Directive on Confirmation of Approval of Stockholm Convention on Persistent Organic Pollutants. Official Gazette No: 27200, 14 April, 2009, Legislation No: 5871, Date of Approval of the Legislation: 2 April 2009. http://www. resmigazete.gov.tr/main.aspx?home $=$ http://www.resmigazete.gov.tr/eskiler/ 2009/04/20090414.htm\&main = http://www.resmigazete.gov.tr/eskiler/2009/04/ 20090414.htm, Accessed date: 10 February 2017.

Official Gazette, 2009b. Decision on Approval of Stockholm Convention on Persistent Organic Pollutants. Official Gazette No: 27304, 30 July, 2009, Decision No: 2009/ 15272. http://www.resmigazete.gov.tr/eskiler/2009/07/20090730-2.htm, Accessed date: 10 February 2017.

Parnis, J.M., Eng, A., Mackay, D., Harner, T., 2016. Characterizing PUF disk passive air samplers for alkyl-substituted PAHs: measured and modelled PUF-AIR partition coefficients with COSMO-RS. Chemosphere 145, 360-364.

Pozo, K., Harner, T., Shoeib, M., Urrutia, R., Barra, R., Parra, O., Focardi, S., 2004. Passive-sampler derived air concentrations of persistent organic pollutants on a north - south transect in Chile. Environ. Sci. Technol. 38, 6529-6537.

Pozo, K., Harner, T., Wania, F., Muir, D.C.G., Jones, K.C., Barrie, L.A., 2006. Toward a global network for persistent organic pollutants in Air: results from the GAPS study. Environ. Sci. Technol. 40, 4867-4873.

Pozo, K., Harner, T., Chi, L., Wania, F., Muir, D., Jones, K.C., 2009. Seasonally resolved concentrations of persistent organic pollutants in the global atmosphere from the first year of the GAPS study. Environ. Sci. Technol. 43, 796-803.

Pozo, K., Harner, T., Lee, S.C., Sinha, R.K., Sengupta, B., Loewen, M., Geethalakshmi, V., Kannan, K., Volpi, V., 2011. Assessing seasonal and spatial trends of persistent organic pollutants (POPs) in Indian agricultural regions using PUF disk passive air samplers. Environ. Pollut. 159, 646-653.

Pozo, K., Harner, T., Rudolph, A., Oyola, G., Estellano, V.H., Ahumada-Rudolph, R., Garrido, M., Pozo, K., Mabilia, R., Focardi, S., 2012. Survey of persistent organic pollutants (POPs) and polycyclic aromatic hydrocarbons (PAHs) in the atmosphere of rural, urban and industrial areas of Concepcion, Chile, using passive air samplers. Atmos. Pollut. Res. 3, 426-434.

Schrlau, J.E., Geiser, L., Hageman, K.J., Landers, D.H., Simonich, S.M., 2011. Comparison 
of lichen, conifer needles, passive air sampling devices, and snowpack as passive sampling media to measure semi-volatile organic compounds in remote atmospheres. Environ. Sci. Technol. 45 (24), 10354-10361.

Shoeib, M., Harner, T., 2002. Using measured octanol-air partition coefficients to explain environmental partitioning of organochlorine pesticides. Environ. Toxicol. Chem. 21, 984-990.

Sjödin, A., Jakobsson, E., Kierkegaard, A., Marsh, G., Sellström, U., 1998. Gas chromatographic identification and quantification of polybrominated diphenyl ethers in a commercial product, Bromkal 70-5DE. J. Chromatogr. A 822, 83-89.

Stafilov, T., Skrbic, B., Klanova, J., Cupr, P., Holoubek, I., Kocov, M., Durisic- Mladenovic, N., 2011. Chemometric assessment of the semivolatile organic contaminants content in the atmosphere of the selected sites in the Republic of Macedonia. J. Chemometr. $25,262-274$.

Stapleton, H.M., Harner, T., Shoeib, M., Keller, J.M., Schantz, M.M., Leigh, S.D., Wise, S.A., 2006. Determination of polybrominated diphenyl ethers in indoor dust standard reference materials. Anal. Bioanal. Chem. 384, 791-800.

Stockholm Convention, 2008. Draft Risk Management Evaluation for Commercial Octabromodiphenyl Ether. Persistent Organic Pollutants Review Committee (POPRC) available at: http://chm.pops.int/Portals/0/Repository/comments_draftRME2008/ UNEP-POPS-POPRC-DRME-08-IPEN-OBDE.English.pdf, Accessed date: 29 November 2017.

Stockholm Convention, 2017. Stockholm Convention on Persistent Organic Pollutants (POPs). available at: http://chm.pops.int/ Accessed November 2017.

Su, Y., Hung, H., Blanchard, P., Patton, G.W., Kallenborn, R., Konoplev, A., Fellin, P., Li, H., Geen, C., Stern, G., Rosenberg, B., Barrie, L.A., 2006. Spatial and seasonal variations of hexachlorocyclohexanes (HCHs) and hexachlorobenzene (HCB) in the arctic atmosphere. Environ. Sci. Technol. 40, 6601-6607.

Sundström, G., Hutzinger, O., 1976. Environmental chemistry of flame retardants V. The composition of Bromkal 70-5 DE-A pentabromodiphenyl ether preparation. Chemosphere 5, 187-190.

Tuduri, L., Harner, T., Hung, H., 2006. Polyurethane foam (PUF) disks passive air samplers: wind effect on sampling rates. Environ. Pollut. 144, 377-383.

Turgut, C., Atatanir, L., Mazmanci, B., Mazmanci, M.A., Henkelmann, B., Schramm, K.W., 2012. The occurrence and environmental effect of persistent organic pollutants (POPs) in Taurus Mountains soils. Environ. Sci. Pollut. Res. 19, 325-334.

Ugranli, T., Gungormus, E., Kavcar, P., Demircioglu, E., Odabasi, M., Sofuoglu, S.C., Lammel, G., Sofuoglu, A., 2016. POPs in a major conurbation in Turkey: ambient air concentrations, seasonal variation, inhalation and dermal exposure, and associated carcinogenic risks. Environ. Sci. Pollut. Res. 23, 22500-22512.

UNEP, 2007. Guidance on the Global Monitoring Plan for Persistent Organic Contaminants. Secretariat of the Stockholm Convention on Persistent Organic Pollutants United Nations Environment Programme-International Environment House, Chatelaine, Geneva, Switzerland, pp. 145 UNEP/CHEMICALS/2007/2.

Vardar, A., Eker, B., 2003. Recommendations on wind turbines to be established in Thracian rural areas in Turkey. In: 2nd Symposium on Renewable Energy Resources, 15-18 October, Izmir, Turkey.
Vijgen, J., Yi, L.F., Forter, M., Lal, R., Weber, R., 2006. The legacy of lindane and technical HCH production. Organohalogen Compd. 68, 899-904.

Vilavert, L., Nadal, M., Schuhmacher, M., Domingo, J.L., 2014. Seasonal surveillance of airborne PCDD/Fs, PCBs and PCNs using passive samplers to assess human health risks. Sci. Total Environ. 466, 733-740.

Voigt, K., Bruggemann, R., Scherb, H., Cok, I., Mazmanci, B., Mazmanci, M.A., Turgut, C., Schramm, K.-W., 2013. Evaluation of organochlorine pesticides in breast milk samples in Turkey applying features of the partial order technique. Int. J. Environ. Health 23 (3), 226-246.

Wang, X.P., Gong, P., Yao, T.D., Jones, K.C., 2010. Passive air sampling of organochlorine polychlorinated biphenyls, and polybrominated diphenyl ethers across the Tibetan plateau. Environ. Sci. Technol. 44, 2988-2993.

Wang, D.G., Alaee, M., Guo, M.X., Pei, W., Wu, Q., 2014. Concentration, distribution, and human health risk assessment of endosulfan from a manufacturing facility in Huai'an, China. Sci. Total Environ. 491, 163-169.

Wania, F., Dugani, C.B., 2003. Assessing the long-range transport potential of polybrominated diphenyl ethers: a comparison of four multimedia models. Environ. Toxicol. Chem. 22, 1252-1261.

Wania, F., Shen, L., Lei, Y.D., Teixeira, C., Muir, D.C.G., 2003. Development and calibration of a resin-based passive sampling system for monitoring persistent organic pollutants in the atmosphere. Environ. Sci. Technol. 37, 1352-1359.

WDNRL (Wisconsin Department of Natural Resources Laboratory Certification Program), 1996. Analytical Detection Limit Guidance and Laboratory Guide for Determining Method Detection Limits, Report No: PUBL-TS-056-96. pp. 24.

Weber, J., Halsall, C.J., Muir, D., Teixeira, C., Small, J., Solomon, K., Hermanson, M., Hung, H., Bidleman, T., 2010. Endosulfan, a global pesticide: a review of its fate in the environment and occurrence in the Arctic. Sci. Total Environ. 408 (15), 2966-2984.

Yenisoy-Karakas, S., Oz, M., Gaga, E.O., 2012. Seasonal variation, sources, and gas/ particle concentrations of PCBs and OCPs at high altitude suburban site in Western Black Sea Region of Turkey. J. Environ. Monit. 14, 1365-1374.

Yeo, H.G., Choi, M., Chun, M.Y., Sunwoo, Y., 2003. Concentration distribution of polychlorinated biphenyls and organochlorine pesticides and their relationship with temperature in rural air of Korea. Atmos. Environ. 37 (27), 3831-3839.

Yolsal, D., Salihoglu, G., Tasdemir, Y., 2014. Air-soil exchange of PCBs: levels and temporal variations at two sites in Turkey. Environ. Sci. Pollut. Res. 21, 3920-3935.

Zhang, G., Chakraborty, P., Li, J., Sampathkumar, P., Balasubramanian, T., Kathiresan, K., Takahashi, S., Subramanian, A., Tanabe, S., Jones, K.C., 2008. Passive atmospheric sampling of organochlorine pesticides, polychlorinated biphenyls, and polybrominated diphenyl ethers in urban, rural, and wetland sites along the coastal length of India. Environ. Sci. Technol. 42, 8218-8223.

Zhang, L., Dong, L., Yang, W., Zhou, L., Shi, S., Zhang, X., Niu, S., Li, L., Wu, Z., Huang, Y., 2013. Passive air sampling of organochlorine pesticides and polychlorinated biphenyls in the Yangtze River Delta, China: concentrations, distributions, and cancer risk assessment. Environ. Pollut. 181, 159-166. 